\title{
Phytochemical, Botanical and Biological Paradigm of Astavarga Plants- The Ayurvedic Rejuvenators
}

\author{
Balkrishna $A^{1,2}$, Mishra RK${ }^{1}$, Sharma N², Sharma VK ${ }^{2}$ and Misra L ${ }^{2 *}$ \\ ${ }^{1}$ Dravyaguna Department, Patanjali Bhartiya Ayurvigyan Avum Anusandhan Sansthan, \\ India \\ 2Patanjali Research Foundation, India
}

Review Article

Volume 2 Issue 6

Received Date: July 06, 2018

Published Date: August 24, 2018

${ }^{*}$ Corresponding author. Laxminarain Misra, Patanjali Research Foundation, Haridwar, Uttarakhand 249405, India, Tel: 91-1334240006; Email: laxmisra@hotmail.com

\section{Abstract}

Astavarga is nature's most extravagant group of flowering plants found in Himalayan region. As the name Astavarga indicates, it contains eight medicinal plants belonging to Zingiberaceae, Orchidaceae and Liliaceae family viz, Kakoli, Kshirakakoli, Meda, Mahameda, Jeevak, Risbhaka, Riddhi and Vridddhi. As per Ayurveda this group of medicinal plants is classified as Rasayana (Rejuvenation) and is important constituents of preparations like Chyawanprasha rasayan, Ashtavarga churna, Brimhanigutika and Vajikaraghrita, etc. Astavarga plants are mostly used to treat sexual disorders, physical weakness, body pain, strengthen the immune system and as an overall tonic. The plants under this group have been the subject of limited biochemical phytochemical and biological activities investigations. Taking into consideration the therapeutic significance of Astavarga plants as described in the ancient Ayurvedic system of medicine, the detailed phytochemical and pharmacological studies appear imperative to scientifically validate the ancient claims. Thus, the present review article provides detailed information on the Ayurvedic uses, habit and habitats, botanical descriptions, chemical constituents and biological activities reported for this important group of plants. The chemical structures of the isolated compounds from these plants and their reported biological activities in the literature have also been included. The information provided in the present review may stimulate the researchers to explore their phytochemical and pharmacological properties which have not yet been attempted, comprehensively. It will generate the interest on "reverse pharmacology" approach to validate the knowledge that has been known from ancient times.

Keywords: Astavarga; Ayurvedic Uses; Botanical Description; Phyto-Constituents; Biological Activities 


\section{Journal of Natural \& Ayurvedic Medicine}

\section{Introduction}

Ayurveda is the eternal science of life [1]. It is associated with the noble, excellent and great tradition of Indian ancient Rishis (sages) and is a part of its prosperous and glorious history. Starting from Lord Brahma, various Rishis and Maharishis in the tradition of Daksha, Asvini Kumars, Indra, Atreya, Punarvasu, Dhanvantri, Bharadwaja, Nimi, Kasyapa and other humanists have enriched and protected the prosperous tradition of Ayurveda. It still continues to flow well from ancient times [2]. The Samhitas of Ayurveda are conveyors of this eternal tradition. Lord Dhanvantri described that Ayurveda is the science of life. It is the Veda of life (beneficial, non-beneficial, happy and unhappy factors of life). The main purpose of Ayurveda is to protect the fitness of a healthy person and to mitigate the disorders of a patient [3,4]. Around $80 \%$ of the population of developing countries relies on traditional medicines, mostly from plants, for their primary health care needs. Modern pharmacopeia has around 25\% plant based drugs as well as synthetic analogues based on the pharmacophore from the plants [5,6]. India holds the highest proportion of medicinal plants known for their medicinal value as compared to any country in the world as the Indians have been using plants to cure diseases since ancient times [7]. As the name Astavarga indicates, this important group contains eight medicinal plants belonging to Zingiberaceae, Orchidaceae and Liliaceae family. In Ayurveda this group is reffered to as Rasayana (Rejuvenation) as they display the properties of Jivaniya (Vitality promoter), Vayasthapana (Age-sustainer),
Swasthya Vardhaka (Health promoting), Rogapratirodhaka ksamata vardhaka (Immuno modulator), Shukrajanan (Spermatogenic) [8-11].

The actual identification of these plants became uncertain and illusory due to lack of doctumented literature, sparse knowledge of natural habitat and incorrect identification. Many of these plants have become rare and endangered due to climatic changes also some of them are usually growing in smaller niches and are not visible over larger areas. This is the reason why the Astavarga plants were passing through confusion and anonymity regarding their proper identification. Recent extensive surveys by Acharya Balkrishna have confirmed that the Astavarga is constituted by: Habenaria intermedia D. Don (Riddhi), Habenaria edgeworthii Hook. f. ex Collett (Vriddhi), Crepidium acuminatum (D. Don) Szlach [12]. (Jeevak), Malaxis muscifera Kuntze (Rishbhak), Polygonatum cirrhifolium Royle (Mahamedha), Polygonatum verticillatum Allioni (Medha), Roscoea purpurea Smith (Kakoli) and Lilium polyphyllum D. Don (Kshirkakoli). Among them four belong to the Orchidaceae $(\mathrm{H}$. intermedia, $\mathrm{H}$. edgeworthii, C. acuminatum, M. muscifera), three to the Liliaceae (P. cirrhifolium, P. verticillatum, L. polyphyllum) and one (R. purpurea) to Zingiberaceae family (Table 1). In continuation of our interest in investigating and reviewing some of the Ayurvedic plants, we have taken up the phytochemical, botanical and biological paradigm of Astavarga group to inculcate fresh interest in nurturing and protecting them from extinction [13-21].

\begin{tabular}{|c|c|c|c|c|}
\hline SN & Sanskrit Name & Botanical Name & Family & Common Name \\
\hline 1 & Kakoli & Roscoea purpurea Smith & Zingiberaceae & $\begin{array}{c}\text { Roscoe's lily, roscoe's purple lily, purple roscoea, } \\
\text { cinnamon stick, hardy ginger }\end{array}$ \\
\hline 2 & Kshirakakoli & Lilium polyphyllum D. Don & Liliaceae & White Himalayan lily, white lily, many leaved lily \\
\hline 3 & Jeevak & $\begin{array}{r}\text { Crepidium acuminatum } \\
\text { (D. Don) Szlach. }\end{array}$ & Orchidaceae & The gradually tapering malaxis \\
\hline 4 & Rishbhak & $\begin{array}{r}\text { Malaxis muscifera (Lindl.) } \\
\text { Kunt }\end{array}$ & Orchidaceae & Adder mouth orchid, snake mouth orchid \\
\hline 5 & Meda & $\begin{array}{r}\text { Polygonatum verticillatum } \\
\text { (Linn.) Allioni }\end{array}$ & Liliaceae & Whorled solomon's seal \\
\hline 6 & Mahameda & $\begin{array}{r}\text { Polygonatum cirrhifolium } \\
\text { (Wall.) Royle }\end{array}$ & Liliaceae & $\begin{array}{c}\text { King's solomon's seal, tendril leaf solomon's seal, coiling } \\
\text { leaf solomon's seal, coiling leaf Polygonatum }\end{array}$ \\
\hline 7 & Riddhi & $\begin{array}{r}\text { Habenaria intermedia D. } \\
\text { Don }\end{array}$ & Orchidaceae & $\begin{array}{c}\text { Intermediate Habenaria, white wild orchid, the in } \\
\text { between Habenaria, Raindeer orchid; }\end{array}$ \\
\hline 8 & Vriddhi & $\begin{array}{r}\text { Habenaria edgeworthii } \\
\text { Hook. f. ex Collett }\end{array}$ & Orchidaceae & Edgeworth's habenaria \\
\hline
\end{tabular}

Table 1: Members of Astavarga. 


\section{Journal of Natural \& Ayurvedic Medicine}

\section{Discussion}

All the Astavarga plants contain various phenolic compounds such as catechin (1), gallic acid (2), pcoumaric acid (3), ferulic acid (4), vanillic acid (5), 4hydroxybenzoic acid (6) phloridizin, caffeic acid, chlorogenic acid, 3-hydroxycinnamic acid, ellagic acid, rutin, and trans-cinnamic acid etc., having strong antioxidant potential with ability to prevent DNA damage from oxidative stress, thus are used for strengthening vitality [22]. Astavarga plants are used to increase body fat, restore fractures and cure fever, diabetese and seminal weakness and build up immunity. Due to immense therapeutic potential, these plants are used in different forms, e.g. taila (oil), ghritam (medicated clarified butter), churna (powder) and formulations, including the popular health tonic chyavanprasha, in the traditional medicinal system (TMS) [23-25]. The identification and differentiation of Astavarga plants in terms of botanical description and habitat, a large number of views and publications have appeared [8,11,23,26-29]. Astavarga is also a subject of extensive biochemical investigation but very little is known about phytochemicals present in most of them. Taking the great medicinal importance of Astavarga plants into consideration, bioactivity guided phytochemical investigations have not been properly attempted and it is definitely the need of the hour to scientifically validate the ancient claims. With this idea, here in the present review article, we provide concise information on the Ayurvedic uses, botanical aspects, chemical constituents and biological activities observed for this traditionally important group of plants.

\section{Ayurvedic Uses of Integrated Astavarga Plants}

- The pseudobulbs are sweet, aphrodisiac, and haemostatic, antidiarrhoeal, styptic, antidysenteric, febrifuge, cooling and tonic. It is useful in sterility, vitiated conditions of pitta and vata, semen related weakness, internal and external hemorrhages, dysentery, fever, emaciation, burning sensation and general debility [30-32].

- These medicinal plants are Jivaniya (vitality promoter) and maintain the balance between three doshas of Vatta, Pitta and Kapha. This increases the energy, body strength, glow and other properties of the body [10].

- They are Bramhaniya (body mass promoters) and are described within the Bemhaniyavarga. The Kakoli and Ksir Kakoli from Astavarga plants fall in this category [10].

- The Astavarga plants mitigate the disorder of the body and specifically alleviate Tridosaja disorder in the body to increase the Ayusya (longevity) and slow down the process of aging [10].

- Mahamayurghrita processed with Jivaka and other herbs, is useful in rasaraktadidhatugatvikara, srotaradiindriyavikarasvarabhransa (Aphesia), asthma, cough, facial paralysis, vaginal diseases, blood disorders and semen related problems [33].

- The intake of powder prepared from Jivaka and other herbs mixed with proper quantity of honey and crystal sugar is useful in cough and cardiac diseases [33].

- Vacadi taila processed with Jivaka and other herbs used as anuvasanavasti, is beneficial for gulma, distention, vata associated disorders and urinary incontinence [3].

- Jivaniyagh Rita processed with Jivaka is useful for the whole body vitiated with gout and vata associated disorders [34].

- Citrakadi taila processed with Jivaka and other herbs is useful in vata associated disorders, sciatica, limping, kyphosis, gout and urinary disorders [3].

- Mahapadma taila processed with Jivaka and other herbs is useful in gout and fever [34].

- Jivaniya ghrita processed with Jivaka and other herbs, can be effective in treating gout and other chronic vata associated disorders [34].

- Asthapanavasti processed with Jivaka and other medicinal herbs is useful in treating gulma, metrorrhagia, anaemia, malaria [3].

- The intake of ghrita processed with Devadaru, Kakoli, Jivaka and other medicinal herbs given in proper dose is useful in child emaciation [3].

- Himavanaagada prepared with the powder of Pancavalkala, Jivaka and other herbs, mixed with honey to make a paste and external application of this paste on snake bite reduces the toxicity. It also alleviates other symptoms like oedema, erysipeles, boils, fever and burning sensation [33].

\section{Botanical Description and Ayurvedic Uses}

A summary of the taxonomical details of Astavarga plants have been included in Table 2 and their habitat in Table 3. Their botanical descriptions have been given in Table 4 . Since some of the plants are no more available, their substitutes, currently employed in the commerce, have been covered in Table 5 [35-37]. The current status of their availability is summarized in Table $6[29,38,39]$. The chemical structures of some of the common compounds, isolated from these plants and their biological activities tested so far, have been depicted in Table 7. However, these tested biological activities are associated with the individual compounds and are not related to the Astavarga plants directly. 


\section{Journal of Natural \& Ayurvedic Medicine}

\begin{tabular}{|c|c|c|c|c|c|c|c|c|}
\hline & Kakoli & $\begin{array}{c}\text { Kshira- } \\
\text { kakoli }\end{array}$ & Jeevak & Rishbhak & Meda & Mahameda & Riddhi & Vriddhi \\
\hline Kingdom & Plantae & Plantae & Plantae & Plantae & Plantae & Plantae & Plantae & Plantae \\
\hline Division & TracheophytaTracheophyta & Tracheophyta & Tracheophyta & Tracheophyta & Tracheophyt & TracheophytaTracheophyta \\
\hline Class & Liliopsida & Liliopsida & Liliopsida & Liliopsida & Liliopsida & Liliopsida & Liliopsida & Liliopsida \\
\hline Order & Zingiberales & Liliales & Asparagales & Asparagales & Liliales & Liliales & Asparagales & Asparagales \\
\hline Family & Zingiberaceae & Liliaceae & Orchidaceae & Orchidaceae & Liliaceae & Liliaceae & Orchidaceae & Orchidaceae \\
\hline Genus & Roscoea & Lilium & Crepidium & Malaxis & Polygonatum Polygonatum & Habenaria & Habenaria \\
\hline Species & purpurea & polyphyllum & acuminatum & muscifera & verticillatum & cirrhifolium & intermedia & edgeworthii \\
\hline $\begin{array}{c}\text { Author } \\
\text { name }\end{array}$ & Smith & D. Don & $\begin{array}{c}\text { (D. Don) } \\
\text { Szlach. }\end{array}$ & (Lindl.) Kunt & (Linn.) Allioni & (Wall.) Royle & D. Don & $\begin{array}{c}\text { Hook.f. ex } \\
\text { Collett }\end{array}$ \\
\hline
\end{tabular}

Table 2: Taxonomic Position of Astavarga.

\begin{tabular}{|c|c|c|}
\hline SN & Name & Habitat \\
\hline 1 & $\begin{array}{l}\text { Roscoea purpurea } \\
\text { Smith }\end{array}$ & $\begin{array}{l}\text { Uttarakhand- Mussoorie- Jaberkhet, Mussorrie, Kyarphulli, Company Bagh, Deoban, Tehri- } \\
\text { Nagtibba West of Dhanolti; Uttarkashi- Jamuna Valley, Kharshali, Har-ki-Dun, Chamoli- } \\
\text { Valley of flowers, Gobindghat, Khirsu, Pithoragarh-Tejam jankhola vally, Kalivalley, Sarju } \\
\text { Valley, Nainital- Nainital, Bhowali, Ramgarh, Fatehgarh, Above Malli Tal; Almora-Binsar, } \\
\text { Almora, Lorakhet, Ranikhet to Chaubatia. }\end{array}$ \\
\hline 2 & $\begin{array}{l}\text { Lilium polyphyllumD. } \\
\text { Don }\end{array}$ & $\begin{array}{l}\text { Himachal Pradesh-Hatto peak, Narkanda forests, Chail (Solan district), Sungari-Bahli on } \\
\text { Rampur Road. Jammu \& Kashmir- Gulmarg, Liddar valley. Uttarakhand- Gangotri, } \\
\text { Rainthal, Amardhar, Kedarnath, Madmaheshwar. }\end{array}$ \\
\hline 3 & $\begin{array}{l}\text { Crepidium acuminatum } \\
\text { (D. Don) Szlach. }\end{array}$ & $\begin{array}{l}\text { Himachal Pradesh- Simla-Glen, Boileaugunj, Elysium Hill in forests way to Rani forest, way } \\
\text { from Khajjar to Chamba, Chail, Hattoo, Narkanda. Uttarakhand- Dehradun- Camel back } \\
\text { road, Below Mussoorie bypass road, above barlowgunj, chakrata, jaunsar, Tehri (Magra); } \\
\text { Pauri-Pode khal, Chamoli- Nagnath, Ukhimath, Gopeshwar, Pithoragarh- Sarju Valley, } \\
\text { Berenag, Thal Kedar; Nainital, Bhowali, Ramagarh, Almora-Ranikhet, between Ranikhet- } \\
\text { Chaubatia. }\end{array}$ \\
\hline 4 & $\begin{array}{l}\text { Malaxis muscifera } \\
\text { (Lindl.) Kunt }\end{array}$ & $\begin{array}{l}\text { Himachal Pradesh- Shimla (Mashobra, Fagu, Hatto forests) Rahala forest, Dhanchoo, } \\
\text { Sangla, Chamba. Jammu \& Kashmir- Gulmarg, Datni, Leh. Uttarkhand-Pithoragarh- Tejum } \\
\text { Haya, Bakariudiyar, Ralam Valley, Palangarh, Ralam, Almora-Dwali, Dehradun chakrata, } \\
\text { Deoban Tehri-Masartal, Bokhills, Dhanolti, Way to Nagtibba; Chamoli- Vasukital, Bajmora, } \\
\text { Jumma area, Dunagiri. }\end{array}$ \\
\hline 5 & $\begin{array}{l}\text { Polygonatum } \\
\text { verticillatum (Linn.) } \\
\text { Allioni }\end{array}$ & $\begin{array}{l}\text { Himachal Pradesh- Shimla, Narkanda, Hattoo, Churdhar, Janjelli, Sikari Tibba, } \\
\text { Kamarunagh. Jammu \& Kashmir-Trikuta Hills, Udhampur, Doda area. Uttarakhand- } \\
\text { Ponwalikanta, Tali, Amardhar, Ganganani dhar, Rainthal, Kedarnath, Gangotri, } \\
\text { Madmaheshwar. }\end{array}$ \\
\hline 6 & $\begin{array}{l}\text { Polygonatum } \\
\text { cirrhifolium (Wall.) } \\
\text { Royle }\end{array}$ & $\begin{array}{l}\text { Himachal Pradesh- Shimla, Matiana, Narkanda. Uttarakhand- Mussoorie, Chakrata, } \\
\text { Gaurikund, Rambara, Harshal, Ganganani, Devban, Rainthal, Mandakini Ghati, Bhilangana } \\
\text { Ghati, Ponwali, Kalimath. }\end{array}$ \\
\hline 7 & $\begin{array}{l}\text { Habenaria intermedia } \\
\text { D. Don }\end{array}$ & $\begin{array}{l}\text { Himanchal Pradesh- Koti (Shimla) Summer Hill, Indian Institute of Advance study, Kamana } \\
\text { Hill), Rwanda and Kamarunag (Karsog), Rewalsar hills (Mandi), Shimla (Fagu), Dalhousie } \\
\text { (Chamba), Kinnaur. Jammu \& Kashmir- Azmabad, Poonch, Pirpanjal Range. Uttarakhand- } \\
\text { Dehradun- Mussoorie (Jaberkhet), Camel back road, Company bagh, Bhatta Fall, Kampty } \\
\text { fall; Tehri (Nagtibba) Suakholi, Chamoli- on way to kedarnath, jangal chatti, way to valley of } \\
\text { flowers, Gaurikund (Rambera); Utarrkashi Tons valley, Bhagirathi valley and way to } \\
\text { Dodital. }\end{array}$ \\
\hline
\end{tabular}




\section{Journal of Natural \& Ayurvedic Medicine}

\begin{tabular}{|c|c|l|}
\hline 8 & $\begin{array}{l}\text { Himachal Pradesh- Summer Hills, Shimla, Mountains near Manali, Rahala Forest, Kothi, } \\
\text { Manali, Saraha, Nirmand- Annu, Rwanda, Kamarunag peak, Saptasar above Rawalsar } \\
\text { (Mandi), Chansel, Churdhar, Jangtoo, Chamba, Narkanda. Uttarakhand- Mussoorie- }\end{array}$ \\
$\begin{array}{l}\text { Jaberkhet, Mussorrie, Kyarphulli, Company Bagh, Deoban, Tehri- Nagtibba West of Dhanolti; } \\
\text { Hook.f. ex Collett } \\
\text { Uttarkashi- Jamuna Valley, Kharshali, Har-ki-Dun, Chamoli- Valley of fl owers, Gobindghat, } \\
\text { Khirsu, Pithoragarh- Tejam jankhola vally, Kalivalley, Sarju valley, Nainital- Nainital, } \\
\text { Bhowali, Ramgarh, Fatehgarh, above Malli Tal; Almora- Binsar, Almora, Lorakhet, Ranikhet } \\
\text { to Chaubatia. }\end{array}$ \\
\hline
\end{tabular}

Table 3: Specific Habitat of Astavarga plants.

\begin{tabular}{|c|c|}
\hline SN & NameTaxonomic features \\
\hline 1 & $\begin{array}{l}\text { Roscoea purpurea Smith: Vegetative Characters: } 35-50 \mathrm{~cm} \text { tall, perennial, herb. Rhizome slightly blackish in } \\
\text { colour. Root fibres thick, fleshy, fascicled, slightly light brown in colour. Stem purple coloured, leafy, elongate, } \\
\text { erect and robust. Leaves 5-6, lanceolate, } 15 \mathrm{~cm} \text { long, } 1.2-2.5 \mathrm{~cm} \text { wide, at flowering time sheath broad, imbricated } \\
\text { leaf-sheath green or purple-red with spots. Flowers few, orchid like in a sessile spike. Bracts oblong, hidden in } \\
\text { the sheaths of the upper leaves. Calyx green, } 3.8 \mathrm{~cm} \text { long, slit deeply down one side as the flower expands. } \\
\text { Corolla tube not longer than the calyx, dilated upwards, limb purple rarely pale lilac or white, upper segments } \\
\text { about } 2.5 \mathrm{~cm} \text { long, obovate-cuneate while lower lanceolate, decurved, lip broad deeply bifid. Staminode } \\
\text { oblanceolate, unguiculate, half as long as the upper segment. Fertile stamen as long as the staminode. Anther } \\
\text { tails } 0.4 \mathrm{~cm} \text { long. Capsule cylindrical, } 2.5-3.8 \mathrm{~cm} \text { long. Seeds ovoid, minute, arillate. Flowering June-July. Fruiting } \\
\text { August-September [40] }\end{array}$ \\
\hline 2 & $\begin{array}{l}\text { Lilium polyphyllum D. Don: A narrow bulbous herb with fleshy scales long narrow, subequal. Stem } 60-120 \mathrm{~cm} \\
\text { erect, slender. Leaves alternate, lower whorled, lanceolate to linear-lanceolate, } 5-13 \mathrm{~cm} \text { long and } 0.5-1.5 \mathrm{~cm} \\
\text { wide, acute, margin hairy. Raceme } 4-10 \text { flowered. Bracts whorled. Flowers pendulous, fragrant. Pedicel } 4-10 \mathrm{~cm} \\
\text { long, slightly drooping. Tepals dull yellow or greenish outside, white within with purple streaks, } 3-4 \mathrm{~cm} \text { long, } \\
\text { oblanceolate. Stamens exserted. Anthers } 1.3 \mathrm{~cm} \text { long. Style very declinate. Fruit capsule. Flowering/fruiting } \\
\text { August-Lilium polyphyllum D. Don: A narrow bulbous herb with fleshy scales long narrow, subequal. Stem } 60- \\
120 \mathrm{~cm} \text { erect, slender. Leaves alternate, lower whorled, lanceolate to linear-lanceolate, } 5-13 \mathrm{~cm} \text { long and } 0.5-1.5 \\
\mathrm{~cm} \text { wide, acute, margin hairy. Raceme } 4-10 \text { flowered. Bracts whorled. Flowers pendulous, fragrant. Pedicel } 4-10 \\
\mathrm{~cm} \text { long, slightly drooping. Tepals dull yellow or greenish outside, white within with purple streaks, } 3-4 \mathrm{~cm} \text { long, } \\
\text { oblanceolate. Stamens exserted. Anthers } 1.3 \mathrm{~cm} \text { long. Style very declinate. Fruit capsule. }\end{array}$ \\
\hline & Flowering/fruitingAugust-November[40]. \\
\hline 3 & $\begin{array}{l}\text { Crepidium acuminatum (D. Don) Szlach: Terrestrial, sometimes epiphytic orchid. Stem cylindric, } 1.5-7 \mathrm{~cm} \\
\text { long, 4- } 6 \mathrm{~mm} \text { in diameter, fleshy with several nodes, mostly enclosed in sheath. Leaves } 3-5 \text {, obliquely ovate, } \\
\text { ovate-oblong or sub-elliptical, } 4-12 \times 2.5-6 \mathrm{~cm} \text { long and wide, base contracted into a sheath-like, amplexicaul } 2-4 \\
\mathrm{~cm} \text { long petiole, apex acuminate. Peduncle } 12-43 \mathrm{~cm} \text {, wingless. Rachis erect, } 3-16 \mathrm{~cm} \text { long, } 10 \text { or more flowered. } \\
\text { Floral bracts lanceolate, } 3-6 \mathrm{~mm} \text { long. Flowers purple red, } 1.5 \mathrm{~cm} \text { in diameter. Pedicel and ovary } 7-10 \mathrm{~mm} \text {. } \\
\text { Dorsal sepal narrowly oblong or broadly linear, } 8-9 \times 2 \mathrm{~mm} \text { size, } 3 \text {-veined, margin revolute, apex obtuse. Lateral } \\
\text { sepals oblong, } 6-7 \times 3-3.5 \mathrm{~mm} \text { size, margin revolute, apex obtuse. Petals narrowly linear, } 8-9 \times 0.8 \mathrm{~mm} \text { size, } \\
\text { margin revolute. Lip (labellum) superior, ovate-oblong or obovate-oblong in outline, } 10-11 \times 6-7 \mathrm{~mm} \text { size, } \\
\text { shallowly bilobed. Auricles narrowly ovate, } 1 / 5-2 / 5 \text { length of lip. Column } 1-1.5 \mathrm{~mm} \text {, stout. Capsule obovoid- } \\
\text { oblong, } 1.8 \times 1 \mathrm{~cm} \text { size. Fruiting pedicel } 7 \mathrm{~mm} \text { long. Flowering and fruiting May-July (111) [41]. }\end{array}$ \\
\hline 4 & $\begin{array}{l}\text { Malaxis muscifera (Lindl.) Kunt: A terrestrial herb upto } 40 \mathrm{~cm} \text { tall. Pseudobulb small, ovoid. Stem flexuous. } \\
\text { Leaves 3-5, unequal, approximate blade of larger leaves } 2-10 \times 1-4 \mathrm{~cm} \text { long and wide while blade of smaller } 1.5-6 \\
\text { x 0.5-3 } \mathrm{cm} \text { long and wide, elliptic to oblong or oblong- lanceolate, obtuse or acute or sub-acuminate. Sheathing } \\
\text { petiole } 2-6 \mathrm{~cm} \text { long. Inflorescence } 2.5-25 \mathrm{~cm} \text { long. Flowers yellowish-green. Bracts slightly shorter than } \\
\text { pedicelled ovary. Sepals subequal, } 2-2.3 \mathrm{~mm} \text { long, oblong-lanceolate. Dorsal sepal directed downwards, laterals } \\
\text { upwards. Petals linear, spreading. Labellum fleshy, broadly ovate, } 2 \mathrm{~mm} \text { long, basal portion excavated, obscurely } \\
\text { angled on either side of base, apex acuminate. Column very short, anthers sessile on its top. Pollinia ovoid and }\end{array}$ \\
\hline
\end{tabular}




\section{Journal of Natural \& Ayurvedic Medicine}

\begin{tabular}{|c|c|}
\hline & $\begin{array}{l}\text { licelled ovary up to } 3 \mathrm{~mm} \text { long, pedicel twisted. Fruit capsule, 6-8 } \mathrm{mm} \text { long, broadly ovoid-oblong, ribbed } \\
\text { ght yellow colour. Flowering- fruiting August- November [40]. }\end{array}$ \\
\hline 5 & $\begin{array}{l}\text { Polygonatum verticillatum (Linn.) Allioni: Rhizome usually shortly branched, tuberous terete, very rarely } \\
\text { moniliform, } 0.7-1.5 \mathrm{~cm} \text { thick. Stem erect, } 20-80 \mathrm{~cm} \text { long, glabrous. Leaves in whorls of } 3 \text {, occasionally alternate } \\
\text { near base of stem, sometimes opposite near apex of stem, subsessile, oblong-lanceolate to linear, } 6-10 \times 0.5-3 \mathrm{~cm} \\
\text { long and wide, apex acute to acuminate, not cirrose. Inflorescences } 1-4 \text { flowered. Flowers pendulous. Peduncle } \\
1-2 \mathrm{~cm} \text { long. Bracts small or absent. Pedicel } 3-10 \mathrm{~mm} \text { long. Perianth pale purple or white or pale yellow, but } \\
\text { probably only when dry, cylindric, } 0.8-1.2 \mathrm{~cm} \text { long. Tepals connate into a tube, } 2-3 \mathrm{~mm} \text { long. Stamens } 6 \text {, with } \\
\text { bare stamens, epipetalous. Filaments } 0.5-2 \mathrm{~mm} \text { long, papillose. Anthers } 2.5 \mathrm{~mm} \text { long. Ovary } 3 \mathrm{~mm} \text {. Style } 2.5-3 \\
\text { mm long. Berries red, } 6-9 \mathrm{~mm} \text { in diameter, } 6-12 \text { seeded. Flowering May-June and fruiting August-October } \\
\text { [40,41]. }\end{array}$ \\
\hline 6 & $\begin{array}{l}\text { Polygonatum cirrhifolium (Wall.) Royle: Rhizome moniliform or tuberous, terete, } 1-2 \mathrm{~cm} \text { thick. Stem erect or } \\
\text { scandent, } 30-90 \mathrm{~cm} \text { long, glabrous. Leaves in whorls of 3-6, rarely a few alternate in proximal part of stem, } \\
\text { sessile, narrowly linear to linear-lanceolate, very rarely oblong-lanceolate, margin entire, } 4-12 \mathrm{~cm} \times 2-15 \mathrm{~mm} \\
\text { long and wide, tip usually cirrose at anthesis. Inflorescences usually } 2 \text {-flowered. Flowers pendulous. Peduncle } \\
0.3-1 \mathrm{~cm} \text { long. Bracts } 1-2 \mathrm{~mm} \text {, scarious, veinless or bract absent. Pedicel } 3-8 \mathrm{~mm} \text {. Perianth white, greenish or } \\
\text { pale purple, subcylindric, slightly constricted in middle, } 8-11 \mathrm{~mm} \text { long. Tepals } 2 \mathrm{~mm} \text { long. Filaments } 0.6-0.8 \times \\
0.15 \mathrm{~mm} \text { size, papillose. Anthers } 2-2.5 \mathrm{~mm} \text {. Ovary } 2.5 \mathrm{~mm} \text {. Style } 2 \mathrm{~mm} \text {. Berries red or purple-red, } 8-9 \mathrm{~mm} \text { in } \\
\text { diameter, 4-9-seeded. Flowering May-July and fruiting September-October [40,41]. }\end{array}$ \\
\hline 7 & $\begin{array}{l}\text { Habenaria intermedia D. Don: Plants turning black when dried, } 23-30 \mathrm{~cm} \text { tall. Tubers ellipsoid, } 1.5-3 \times 1-2 \mathrm{~cm} \\
\text { size, fleshy. Stem erect, terete, stout. Leaves 3-5, laxly arranged. Leaf blade ovate-lanceolate, } 3.5-8 \times 2-4 \mathrm{~cm} \text { long } \\
\text { and wide, base amplexicaul, apex acute. Raceme 1-4-flowered, } 6-15 \mathrm{~cm} \text { long. Flowers large, green and white. } \\
\text { Floral bracts ovate, } 4-5 \mathrm{~cm} \text { long, nearly as long as ovary, apex acuminate. Ovary twisted, terete, including pedicel } \\
3.8-4.5 \mathrm{~cm} \text { long. Flowers white or greenish. Sepals ciliate, green. Dorsal sepal erect, ovate-oblong, concave, } 2.2 \times \\
1.2 \mathrm{~cm} \text { size, 7-veined, apex acute. Lateral sepals reflexed, obliquely falcate-lanceolate, } 3 \times 0.6 \mathrm{~cm} \text { size, } 7-\mathrm{veined} \text {, } \\
\text { apex acute. Petals white, forming a hood with dorsal sepal, erect, white, obliquely subovate-falcate, } 2.2 \times 0.8 \mathrm{~cm} \\
\text { size, 5-veined, margin ciliate, unlobed, apex acute. Lip pale or yellowish-green, } 2.8-3 \mathrm{~cm} \text { size, base spurred, } \\
\text { deeply 3-lobed above base, lobes ciliate. Lateral lobes linear, outer margin with } 10 \text { filiform lobules. Mid-lobe } \\
\text { linear, } 18-20 \mathrm{~mm} \text { long, slightly shorter than lateral lobes, apex acute. Spur pendulous, cylindric, } 7-8.5 \mathrm{~cm} \text { long, } \\
\text { much longer than ovary, slightly dilated near end, apex obtuse. Connective } 2 \text { mm wide. Pollinia ovoid. Caudicles } \\
\text { linear. Viscidia orbicular, small. Rostellum with elongate arms. Stigmas clavate. Flowering July[40,41]. }\end{array}$ \\
\hline 8 & $\begin{array}{l}\text { Habenaria edgeworthii Hook.f. ex Collett: A terrestrial, leafy herb with unidivided, oblong tubers and fleshy } \\
\text { root fibres. Stem with the raceme } 30-47 \mathrm{~cm} \text { long, leafy from about } 5 \mathrm{~cm} \text { upwards, internodes ensheathed by leaf } \\
\text { bases. Leaves erect, } 4-9 \times 0.8-1.2 \mathrm{~cm} \text {, lanceolate, setaceously acuminate, acute, indistinctly } 5-7 \text { veined, bases } \\
\text { sheathing. Flowers } 1.5 \mathrm{~cm} \text { broad when spread out, in elongated terminal racemes. Peduncles as long as the } \\
\text { racemes with about two leafy, sterile, acuminate bracts. Floral bracts leafy, } 2.4 \times 1.1 \mathrm{~cm} \text { long and wide, broadly } \\
\text { lanceolate-ovate, acuminate, acute, initially } 3-5 \text {-veined but soon branching to give a } 9 \text {-veined appearance. Dorsal } \\
\text { sepal } 6 \times 4 \mathrm{~mm} \text { size, oblong-ovate, obtuse, } 3 \text {-veined, lateral veins branching. Lateral sepals } 7 \times 4 \text { mm size, broadly } \\
\text { and obliquely ovate, obtuse, } 3 \text {-veined, the lateral veins branching giving a } 5-7 \text {-veined appearance. Petals } 7 \times 2 \\
\text { mm size, yellowish-green, bilobed, lobes variable in length and breadth. Upper lobe lanceolate, about half as long } \\
\text { as the lower linear lobe, incurved, } 2 \text {-veined. Lip } 5 \times 2 \mathrm{~mm} \text {, purple, inserted at the base of the column, broadly } 3- \\
\text { lobed, fleshy, lobes variable in length, obtuse. Spur } 1.7 \mathrm{~cm} \text { long, narrowly clavate, mouth provided with a ligule. } \\
\text { Column } 3.4 \mathrm{~mm} \text { high, } 3 \mathrm{~mm} \text { broad, with a small, triangular rostellum and two viscid, sausage-shaped stigmas. } \\
\text { Anthers lateral, adnate to the column, } 2 \text {-loculed. Pollinia } 2 \text {, granular, golf club-shaped, stalked, } 1.3-1.6 \times 0.6 \text { mm } \\
\text { size, each with a long slender caudicle } 2.2-2.4 \text { mm long, attached to a minute gland. Staminodes short and fleshy, } \\
\text { arising from the sides of the column and protruding above as granular masses. Ovary with pedicel } 2 \mathrm{~cm} \text { long } \\
\text { [40]. }\end{array}$ \\
\hline
\end{tabular}

Table 4: Botanical features of Astavarga plants. 


\section{Journal of Natural \& Ayurvedic Medicine}

\begin{tabular}{|c|c|c|c|}
\hline SN & Name & Substitute & Reference \\
\hline 1 & Roscoea purpurea Smith & $\begin{array}{c}\text { Aswagandha (Withania somnifera (L.) Dunal) and Kali musali (Curculigo } \\
\text { orchioides Gaertn) }\end{array}$ & [35-37] \\
\hline 2 & $\begin{array}{l}\text { Lilium polyphyllum D. } \\
\text { Don }\end{array}$ & $\begin{array}{l}\text { Aswagandha (Withania somnifera (L.) Dunal), Safed musali (Chlorophytum } \\
\text { arundinaceum Baker), Fritillaria roylei Hook. Fritillaria oxypetala D. Don. }\end{array}$ & {$[35,36]$} \\
\hline 3 & $\begin{array}{l}\text { Crepidium acuminatum } \\
\text { (D. Don) Szlach. }\end{array}$ & $\begin{array}{l}\text { Vidarikand (Pueraria tuberose (Wild.) DC), Safed behmen (Centaurea behen } \\
\text { Linn.) and Guduchi (Tinospora cordifolia (Willd.) Miers, Malaxis } \\
\text { cylindrostachya (Lindl.) Kuntze and Malaxis mackinnoni (Duthie) Ames) }\end{array}$ & {$[35,36]$} \\
\hline 4 & $\begin{array}{l}\text { Malaxis muscifera } \\
\text { (Lindl.) Kunt }\end{array}$ & $\begin{array}{c}\text { Vidarikand (Pueraria tuberose (Willd.) DC.) and Lal behmen (Centaurium } \\
\text { roxburghii (D. Don) Druce }\end{array}$ & {$[35,36]$} \\
\hline 5 & $\begin{array}{c}\text { Polygonatum } \\
\text { verticillatum (Linn.) } \\
\text { Allioni } \\
\end{array}$ & $\begin{array}{c}\text { Satavari (Asparagus racemosus Willd.), Salam mishri (Eulophia campestris } \\
\text { Wall.) }\end{array}$ & {$[35,36]$} \\
\hline 6 & $\begin{array}{l}\text { Polygonatum } \\
\text { cirrhifolium (Wall.) } \\
\text { Royle }\end{array}$ & $\begin{array}{l}\text { Satavari (Asparagus racemosus Willd.), Nagbala (Sida veronicifolia Lam.), } \\
\text { Shakakul mishri (Polygonatum multiflorum (L.) All.) and Prasarani (Paederia } \\
\text { foetida L.). }\end{array}$ & {$[35,36]$} \\
\hline 7 & $\begin{array}{l}\text { Habenaria intermedia D. } \\
\text { Don }\end{array}$ & $\begin{array}{c}\text { Varahikand, Bala (Sida cordifolia L.) and Chiriya musali (Asparagus filicinus } \\
\text { Buch-Ham. ex D. Don) }\end{array}$ & {$[35,36]$} \\
\hline 8 & $\begin{array}{c}\text { Habenaria edgeworthii } \\
\text { Hook.f. ex Collett }\end{array}$ & $\begin{array}{l}\text { Varahikand (Tacca integrifolia Ker Gawl.), Salam panja (Dactylorhiza hatagirea } \\
\text { (D. Don) Soo) and Mahabala (Sidaacuta Burm.f.). Habenaria griffithii Hook.f. }\end{array}$ & {$[35,36]$} \\
\hline
\end{tabular}

Table 5: Substitutes of Astavarga Plants in commerce.

\begin{tabular}{|c|c|c|c|}
\hline SN & Name & Status & Reference \\
\hline 1 & Roscoea purpurea Smith & Commonly available & {$[29,38]$} \\
\hline 2 & Lilium polyphyllum D. Don & Endangered & {$[39]$} \\
\hline 3 & Crepidium acuminatum (D.Don) Szlach. & Rare & {$[39]$} \\
\hline 4 & Malaxis muscifera (Lindl.) Kunt & Rare, Threatened & {$[39]$} \\
\hline 5 & Polygonatum verticillatum (Linn.) Allioni & Threatened & {$[39]$} \\
\hline 6 & Polygonatum cirrhifolium (Wall.) Royle & Rare & {$[39]$} \\
\hline 7 & Habenaria intermedia D. Don & Commonly available & {$[39]$} \\
\hline 8 & Habenaria edgeworthii Hook.f. ex Collett & Rare & {$[39]$} \\
\hline
\end{tabular}

Table 6: Current Status of Astavarga Plants. 


\section{Journal of Natural \& Ayurvedic Medicine}

\begin{tabular}{|c|c|c|}
\hline Name & Chemical Structure & Biological activities \\
\hline Catechin (1) & & $\begin{array}{l}\text { Neuroprotection, anticancer, antioxidant,antiobesity, } \\
\text { antidiabetic,cardioprotection, antiangiogenic [42-48] }\end{array}$ \\
\hline Gallic acid (2) & $\mathrm{OH}$ & $\begin{array}{c}\text { Antidepressant, antiparkinson, antidiabetic, } \\
\text { antimalarial, diuretic, cardioprotective, antiviral, } \\
\text { antifungal, wound healing, anthelmintic, anxiolytic, } \\
\text { anticancer [49-61] }\end{array}$ \\
\hline $\begin{array}{c}\text { p-Coumaric acid } \\
\text { (3) }\end{array}$ & & $\begin{array}{l}\text { Antioxidant, anti-inflammatory, anxiolytic, } \\
\text { antimicrobial, antidiabetic and antihyperlipidemic, } \\
\text { anticancer [62-71] }\end{array}$ \\
\hline Ferulic acid (4) & $\mathrm{OCH}_{3}$ & $\begin{array}{c}\text { Antioxidant, antiallergic, hepatoprotective, } \\
\text { anticarcinogenic, anti-inflammatory, antimicrobial, } \\
\text { antiviral, vasodilatory effect, antithrombotic, and } \\
\text { helps to increase the viability of sperms antidiabetic } \\
\text { and anti-ageing agent, anticancer, improve the } \\
\text { structure and function of the heart, blood vessels, } \\
\text { liver, and kidneys in hypertensive rats, } \beta \text {-secretase } \\
\text { modulator [72-85]. }\end{array}$ \\
\hline Vanillic acid (5) & & Cognitive improvement, ulcerative colitis $[86,87]$. \\
\hline $\begin{array}{l}\text { Hydroxy benzoic } \\
\quad \text { acid (6) }\end{array}$ & & Antimicrobial [88] \\
\hline Scopoletin (7) & & $\begin{array}{l}\text { Cognition-enhancing properties, anti-inflammatory, } \\
\text { antiproliferative agent, inhibitor of nitric oxide } \\
\text { synthase, prostaglandin synthase and monoamine } \\
\text { oxidase, antioxidant and radical scavenger [89-97] }\end{array}$ \\
\hline Mescaline (8) & & Hallucinogenic [98] \\
\hline Cetyl alcohol (9) & & Antimicrobial, emollient [99-100] \\
\hline
\end{tabular}




\section{Journal of Natural \& Ayurvedic Medicine}

\begin{tabular}{|c|c|c|}
\hline Limonene (10) & & $\begin{array}{l}\text { Anticancer, dissolve gall stones, heartburn and } \\
\text { gastroesophageal re-flux disorder (gerd) [101-106] }\end{array}$ \\
\hline Eugenol (11) & & $\begin{array}{c}\text { Antioxidant activity, anti-inflammatory, antibacterial } \\
\text { and antiviral [107-109] }\end{array}$ \\
\hline Citronellal (12) & & Relaxant effect in smooth muscle of trachea [110] \\
\hline 1, 8-Cineole (13) & & $\begin{array}{c}\text { Mucolytic and spasmolytic action on the respiratory } \\
\text { tract benefits in inflammatory airway diseases, such } \\
\text { as asthma and chronic obstructive pulmonary disease } \\
\text { (COPD), antiseptic anthelmintic, anti-inflammatory, } \\
\text { antimicrobial [111-116] }\end{array}$ \\
\hline Piperitone (14) & & Antimicrobial [117-118] \\
\hline p-Cymene (15) & & $\begin{array}{l}\text { Antioxidant, antinociceptive } \& \text { anti-inflammatory, ant } \\
\text { cancer [119-127] }\end{array}$ \\
\hline Diosgenin (16) & & $\begin{array}{l}\text { Antidiabetic, antiobesity, anti-inflammatory, } \\
\text { anticancer [128-130] }\end{array}$ \\
\hline$\beta$-Sitosterol (17) & & $\begin{array}{l}\text { Anti-inflammatory, inducing apoptosis, } \\
\text { chemoprotective, hypocholesterolemic, angiogenic, } \\
\text { analgesic, anthelminthic and anti-mutagenic, } \\
\text { immunomodulatory, anticancer, antidiabetic [131- } \\
146]\end{array}$ \\
\hline $\begin{array}{l}\text { 5-hydroxymethyl } \\
\text { furfural (18) }\end{array}$ & U & $\begin{array}{c}\text { Inhibit sickling of red blood cells, relieve fatigue, } \\
\text { improvement in learning and memory, antioxidative, } \\
\text { anti-apoptotic activity anticarcinogenic action, } \\
\text { antimicrobial, anti-hypoxic effect anti-inflammatory } \\
\text { [147-164] }\end{array}$ \\
\hline
\end{tabular}




\section{Journal of Natural \& Ayurvedic Medicine}

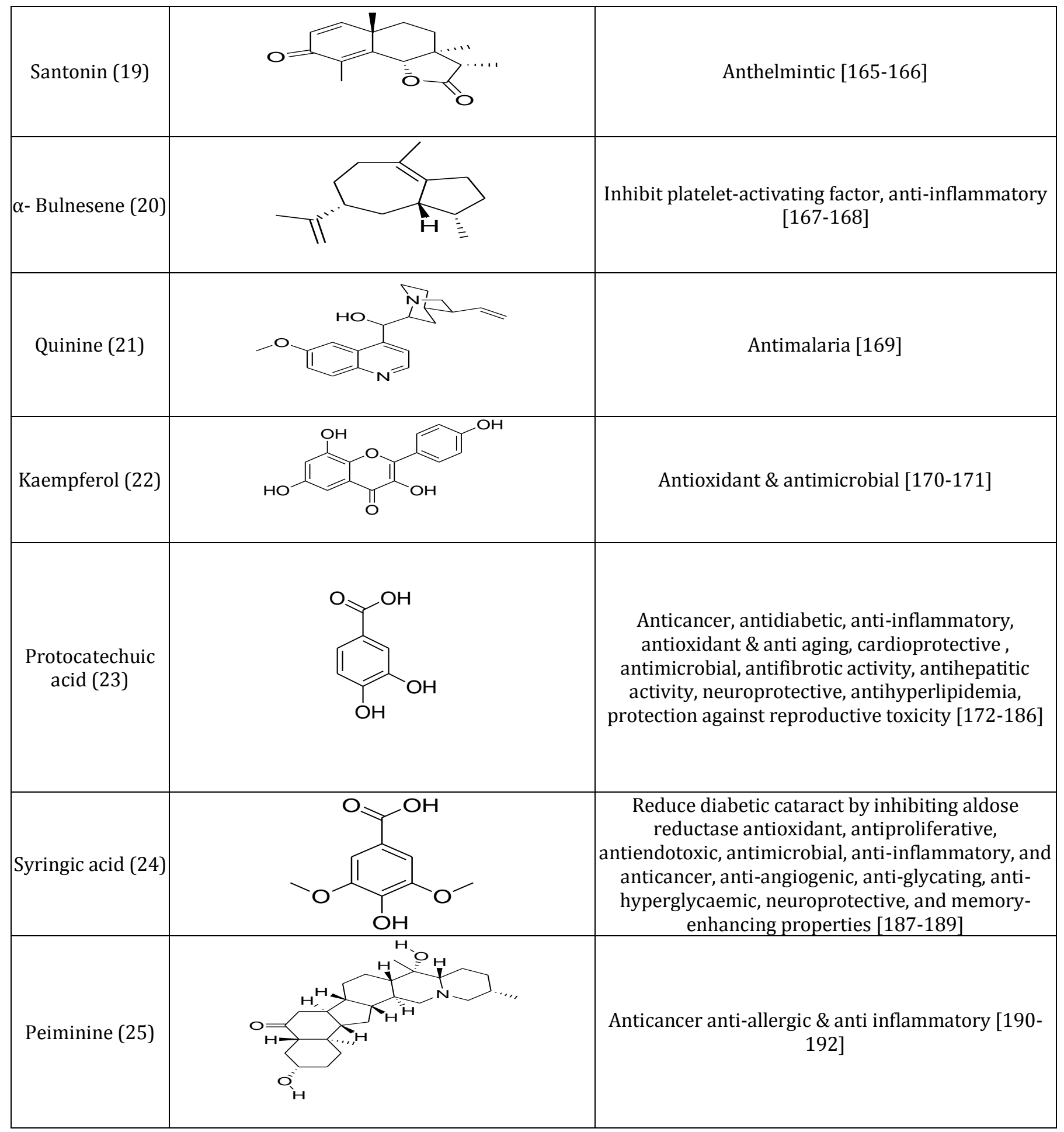

Table 7: Chemical structure and biological activities of some of the compounds from Astavarga plants.

Riddhi (Habenaria edgeworthii syn. Platanthera edgeworthii (Hook.f. ex Collett) RK.Gupta: It belongs to the Family Orchidaceae. The botanical descriptions and habitat has been described in Tables 2 \& 3. It is useful as nerve and cardiac tonic, blood related infections, fever, cough, asthma, muscular pain, sprains, arthritis, gout, 


\section{Journal of Natural \& Ayurvedic Medicine}

sciatica, leprosy, skin diseases, anorexia, emaciation, gout, helminthiasis, insanity, general debility and increase in sperm count $[12,193]$.

Vriddhi (Habenaria intermedia D.Don syn. Habenaria arietina H.f.): It belongs to the Family Orchidaceae. The botanical descriptions and habitat has been described in Tables 2 \& 3. It is useful as aphrodisiac, depurative, anthelmintic, nerve and cardiac tonic. It is also useful in treating respiratory and skin diseases. Habenaria intermedia is a significant constituent of a well acknowledged polyherbal formulation, Chyavanprasha [194,195].

Meda (Polygonatum verticillatum (L.) All syn. Convallaria verticillata $L$ syn. Evallaria verticillata Necker): It belongs to the Family Liliaceae. The botanical descriptions and habitat has been described in Tables 2 \& 3 . It is useful as antipyretic, antimalarial, potential aphrodisiac, appetizer, galactagogue, antifungal and skin tonic [196-199].

Mahameda (Polygonatum cirrhifolium Wall Royle): It belongs to the Family Liliaceae. The botanical descriptions and habitat has been described in Tables 2 \& 3. It is useful in the treatment of loss of vigor, accumulation of fluids in bone joints, skin diseases, tuberculosis, fever, bronchitis and general debility. It is also reported to have hypoglycemic, hypotensive, antibacterial and antifungal effects $[200,201]$.

Jeevaka (Malaxis acuminta D. Don syn. Microstylis wallichii Lindl syn. Malaxis wallichii Deb): It belongs to the Family Orchidaceae. The botanical descriptions and habitat has been described in Tables $2 \& 3$. It is useful as therapeutics in bleeding diathesis, burning sensation, fever, phthisis, tonic, tuberculosis and increasing sperm count [201].

Rishbhaka (Microstylis Muscifera Ridley): It belongs to the Family Orchidaceae. The botanical descriptions and habitat has been described in Tables $2 \& 3$. It is useful for treatment of burning sensation, fever, phthisis, tuberculosis and increasing sperm count.

Kakoli (Roscoea procera Wall. formerly Roscoea purpurea or Fritillaria roylei Hook f.) Family: It belongs to the Family Zingiberaceae. The botanical descriptions and habitat has been described in Tables 2 \& 3 . It is useful as anti-rheumatic, antipyretic, galactagogue, expectorant, sexual stimulant, anti diabetic, anti hypertensive and diuretic. The fleshy roots are conventionally used to treat malaria and urinary infection
[202-204]. Additionally, the ethanolic rhizome extract has immune-stimulatory potential in mice [205].

Kshirakakoli (Lilium polyphyllum D.Don): It belongs to the Family Liliaceae. The botanical descriptions and habitat has been described in Tables $2 \& 3$. It is useful as refrigerant, galactogogue, expectorant, aphrodisiac, diuretic and antipyretic. It is also used in cases of seminal weakness, hyperdipsia, intermittent fever, haematemesis, rheumatalgia and general disability [206].

\section{Chemical and Biological activities}

\section{Habenaria Species}

Both of the Habenaria species are of great therapeutic value in curing asthma, cough, facial paralysis, vaginal diseases and semen related disorders along with their application in rejuvenation [11]. These plants are the important ingredients of 'Chyavanprasha' and are well acknowledged for having anti-ageing properties, helpful in providing protection against degenerative diseases [207].

\section{Habenaria intermedia}

The phytochemical studies on $\mathrm{H}$. intermedia has substantiated that it is effective source of total phenols, thiamine, tannins, and calcium. Antioxidant activity of polyherbal formulation containing tubers of $\mathrm{H}$. intermedia was examined for nitric oxide scavenging activity [208]. Also the content of hydroxybenzoic acid was almost double to that of some of the other species [209]. Presence of various phenolic compounds, such as catechin (1), gallic acid (2), $\rho$-coumaric acid (3), hydroxybenzoic acid (6), and scopoletin (7) supports them as the promising source of antioxidants [210-213]. In various fractions of $\mathrm{H}$. intermedia, adaptogenic activity was also studied using immobilization induced acute stress (AS), chronic stress (CS) and swimming induced stress in experimental animals, which proved it as anti-stress agent [210].

Gallic acid (2) is a well known starting material for the synthesis of the psychedelic alkaloid mescaline (8) and has shown antioxidant and cytotoxic activities. Scopoletin (7) is a naturally occurring coumarin found in various medicinal plants with wide range of biological activities. Recent studies demonstrated that scopoletin (7) has anticonvulsant, antioxidant, antimicrobial, hypotensive, anticancer activities and prevents lipid peroxidation [214223]. It also possesses antidepressant-like effect which is dependent on the serotonergic, noradrenergic and dopaminergic systems [224]. 


\section{Journal of Natural \& Ayurvedic Medicine}

\section{Habenaria egdeworthii}

Very little information is available on the scientific work done on $\mathrm{H}$. egdeworthii. However, it has been found to be a rich source of sodium and possesses antioxidant activity [208].

\section{Malaxis Species}

The plant species is used for the cure of tuberculosis and is a great aphrodisiac [225]. It is also known as febrifuge, tonic and useful in the conditions of sterility, seminal weakness, hemorrhages, dysentery, emaciation, burning sensation as well as general debility [12]. However, the investigation of its phyto-constituents is inadequate.

\section{Malaxis acuminata}

Bhatnagar, et al. reported $\beta$-sitosterol (17), cetyl alcohol (9), choline and two sugars namely glucose and rhamnose from Malaxis acuminate [226]. The thin layer chromatographic studies revealed the presence of constituents like limonene (10), eugenol (11), citronellal (12), 1,8-cineole (13), piperitone (14) and p-cymene (15) [227]. Atomic absorption spectroscopy indicated the presence of $\mathrm{Cu}, \mathrm{Zn}, \mathrm{Mn}, \mathrm{Fe}, \mathrm{K}, \mathrm{Ca}, \mathrm{Mg}, \mathrm{Al}, \mathrm{Ba}, \mathrm{B}, \mathrm{Mo}$ and $\mathrm{Cl}$. The fatty acid analysis using GC-MS revealed the identification of common fatty acids including, linoleic acid, $\alpha$-linolenic acid, oleic acid, palmitic acid, stearic acid, $\gamma$-linolenic acid, eicosanoic acid, eicosenoic acid and eicosadienoic acid [228]. The antioxidant activity in butanol extract of M. acuminata was observed using various available methods like, DPPH free radical scavenging activity, and hydrogen peroxide scavenging method [229].

\section{Malaxis muscifera}

(Syn. Dienia muscifera, Microstylis muscifera) is listed as a threatened species in IUCN Red List due to uncontrolled grazing unsustainable collection and unregulated trade [230]. There is an urgent need for developing sustainable cultivation, in situ and ex situ policies which can help to maintain the population.

\section{Polygonatum Species}

It is documented in "Abhinav niguntu" that "Meda" grows from the same place from where "Mahameda" originates, suggesting that both P. verticillatum and P. cirrhifolium grows together. The term "Meda" represents the mucilage present inside the rhizomes of these plant species [231]. Both species are perennial rhizomatous herbs with their habitation in the extensive range from
Europe to the Himalayas to Siberia. They are used for treating pain, pyrexia, burning sensation, phthisis, appetizer, increase milk secretion, for gastric problems, improving sexual potency and improve general weakness $[200,232]$.

\section{Polygonatum verticillatum}

It contains phyto-constituents such as lysine, serine, aspartic acid, threonine, diosgenin (16), $\beta$-sitosterol (17), sucrose, along with the micronutrients and macronutrients [12]. It is also rich in saponins, alkaloids, glycosides, flavonoids and phytohormones. Few compounds have been isolated from the rhizomes of $\mathrm{P}$. verticillatum which include lectins, 5-hydroxymethyl-2-furaldehyde (18) diosgenin, santonin (19), $\beta$-sitosterol (17), 2-hydroxybenzoic acid, $\alpha$ bulnesene (20) and quinine (21) [199,233-237].

The rhizome extract of $\mathrm{P}$. verticillatum is used as tonic and energizer. It has also been studied for antimalarial and antioxidant, metal accumulating, insecticidal, antibacterial, antipyretic, tracheorelaxant and antiinflammatory, antispasmodic and antidiarrheal, antinociceptive, aphrodisiac [199,235,238-242]. Lipoxygenase, urease inhibition, anti tyrosinase activity of the aerial parts of the P. verticillatum was also observed which were attributed to the presence of saponins, alkaloids, flavonoids, phenols, tannins and terpenoids in considerable amount [243-245].

\section{Polygonatum cirrhifolium}

It is reported to be used as a tonic in major Ayurvedic formulations like Asoka Ghrita, Sivagutika, Amrtaprasa Ghrita, Dasam, Ularista, Dhanvantara Taila, Brhatmasa Taila, Mahanarayana Taila and Vasacandanadi Taila [231]. A root infusion with milk is used as an aphrodisiac and blood purifier [200]. P. cirrhifolium is reported to have hypoglycemic, hypotensive, antibacterial, antifungal and antioxidant activities [22,201]. Its rhizomes are rich in starch, protein, pectin and asparagine [246].

\section{Roscoea procera}

Tubers of Kakoli are found to contain alkaloid, glycoside, flavonoid, tannin, saponins and active phenolic compounds and are reported to exhibit immunomodulatory and anti-diabetic activities [205,247]. Quantification of metabolites suggested that the tubers are nutritionally rich having appreciable content of fiber (28.1\%), protein (3.46\%) and oil (3.5\%). Quantification of secondary metabolites through HPTLC reveals that kaempferol (22) $(0.30 \%)$ was the major metabolite 


\section{Journal of Natural \& Ayurvedic Medicine}

followed by vanillic acid $(0.27 \%)$, protocatechuic acid (23) $(0.14 \%)$, syringic acid (24) $(0.08 \%)$ and ferulic acid (0.05\%). In addition to this, there exists a positive, significant correlation between the phenolic and flavonoids content with the anti-oxidant activity of Roscoea extract [204]. HPTLC results of kakoli (ethanol and chloroform extracts) revealed the presence of alkaloids, glycosides and flavonoids [248]. Propeimin, peimine, peiminine (25), peimisine, kashmirine and sipeimine have also been reported [194,249-253].

\section{Lilium Polyphyllum}

Its bulbs have been used for diuretic, antipyretic, tonic in seminal weakness, in asthma, bronchitis and tuberculosis [8,254-257]. Phytoconstituents like alkaloids (peimine, peiminine, peimisine, peimiphine, peimidine and peimitidine), neutral constituents (propeimin, sterol) are reported to be present in Kshirkakoli [251]. Its HPTLC finger printing (ethyl acetate and chloroform extract) indicated the presence of saponins and steroids [248].

\section{Conclusion}

Astavarga is an important group of medicinal plants reported in old literature, however, the detailed information on the medicinal use was restricted as it was retained by the indigenous population and was transferred to the next generations through words of mouth $[9,258,259]$. As the scientific research conducted on Astavarga is limited, the information provided in the present review regarding the chemical constituents and biological activities along with their botanical aspects and Ayurvedic paradigm will be beneficial to the researchers to explore novel phytochemical and medicinal properties which were not investigated earlier. Further work on chemistry and biology of alkaloids needs to be strengthened to understand their active therapeutic roles in the Ayurvedic preparations. Additionally, the emphasis has been given to understand the Ayurvedic uses of these medicinal plants and the present review will generate fresh interest for their conservation and "reverse pharmacology" approach to validate the information that has been known for long time.

\section{References}

1. Pandeya G, Sashtri K (2011) Charaka Samhita (part I) (Sanskrit-Hindi) Chaukhambha Bharatee Academy, Varanasi, India, pp: 587.

2. Gupta A (2005) Astanga-samgraha. Varanasi, India: Chaukhambha Krishna Das Academy, pp: 2.
3. Sharma AR (2012) Sushruta Samhita (Part-1). Varanasi, India: Chaukhambha Sankrit Pratisthan, pp: 10.

4. Sharma I, Singh A (2017) Clinical Studies with Ayurvedic Formulations-A Practitioner's Preview. J Nat Ayurvedic Med 1(1): 1-5.

5. Farnsworth NR (1994) Ethnopharmacology and drug development. Ciba Found Symp 185: 42-59.

6. Mukherjee PK, Wahile A (2006) Integrated approaches towards drug development from Ayurveda and other Indian system of medicines. J Ethnopharmacol 103(1): 25-35.

7. Kala C, Dhyani P, Sajwan B (2006) Developing the medicinal plants sector in northern India: challenges and opportunities. J Ethnobiol Ethnomed 2(1): 32-36.

8. Dhyani A, Nautiyal B, Nautiyal M (2010) Importance of Astavarga plants in traditional systems of medicine in Garhwal, Indian Himalaya. Int J Biodiver Sci Ecosys Serv Manag 6(1-2): 13-19.

9. Mathur DR (2003) Yogtarangini. Chaukhamba Vidhyabhawan, Varanasi (India).

10. Pandey D (2005) Sarangadharasanhita. Chaukhamba Amarabharati Prakashan, Varanasi, India.

11. Sharma BD, Balkrishna A (2005) Vitality strengthening Astavargaplants (Jeevaniya \& Vayasthapan Paudhe), Uttaranchal (India), Divya Publishers, Divya yog mandir Trust, Haridwar.

12. Balkrishna A (2012a) Secrets of Astavarga Plants (for vitality and anti-aging). Haridwar, Uttarakhand, India: Divya Prakashan, Patanjali Yogpeeth, pp: 1-104.

13. Siddique AA, Bhakuni RS, Misra LN, Gupta P, Darokar MP (2017) New triglyceride from antimicrobials extracts of Nepeta hindostana weed. In J Chem 56B(5): 542-550.

14. Tewari R, Rout PK, Misra LN (2016) Simultaneous RPHPLC-PDA-RI separation and quantification of pinitol content in Sesbania bispinosa vis-à-vis harvesting age. Plant Biosyst 151(5): 924-930.

15. Gupta M, Rout PK, Misra LN, Gupta P, Singh, N, et al. (2016) Chemical composition and bioactivity of Boswellia serrata Roxb. Essential oil in relation to geographical variation. Plant Biosys 151(4): 623-629. 


\section{Journal of Natural \& Ayurvedic Medicine}

16. Ahmad F, Misra L, Tewari R, Gupta P, Gupta VK, et al. (2016a) Isolation and HPLC profiling of chemical constituents of Saraca asoca bark. Indian J Chem B 55B: 353-361.

17. Ahmad F, Misra L, Tewari R, Gupta P, Mishra P, et al. (2016b) Anti-inflammatory flavanol glycosides from Saraca asoca bark. Nat Prod Res 30: 489-492.

18. Ahmad F, Misra L, Gupta VK, Darokar MP, Prakash O, et al. (2015) Synergistic effect of (+)-pinitol from Saraca asoca with $\beta$-lactam antibiotics and studies on the in silico possible mechanism. J Asian Nat Prod Res 18(2): 172-183.

19. Balkrishna A, Misra LN (2017a) Ayurvedic plants in brain disorders: the herbal hope. J Tradit Med Clin Natur 6(2): 1-9.

20. Balkrishna A, Misra LN (2017b) Ayurvedic opportunities for restoration of skin health. J Tradit Med Clin. Natur 6(2): 221.

21. Balkrishna A, Misra LN (2018) Chemo-botanical and neurological accounts of some Ayurvedic plants useful in mental health. Nat Prod J 8(1): 14-31.

22. Giri L, Belwal T, Bahukhandi A, Suyal R, Bhatt ID, et al. (2017) Oxidative DNA damage, protective activity and antioxidant potential of Astavarga species growing in the Indian Himalayan region. Indust Crops Prod 102: 173-179.

23. Balkrishna A (2012a) Secrets of Astavarga Plants (for vitality and anti-aging). Haridwar, Divya Prakashan, Patanjali Yogpeeth, Uttarakhand, India, pp: 1-104.

24. Balkrishna A, Srivastava A, Mishra RK, Patel SP, Vashistha RK, et al. (2012b) Astavarga plantsthreatened medicinal herbs of North -West Himalaya. Int J Med Arom Plants 6: 661-676.

25. Ghosh A, Damiki L, Singh NK (2013) Comparative estimation and chemical standardization of new and old sample of Chyawanprash. Int J Pharm Pharm Sci 5(3): 801-804.

26. Osmaston AE (1978) A Forest Flora for Kumaon. Bishen Singh Mahinder Pal Singh, Dehradun, India.

27. Naithani BD (1985) Flora of Chamoli II, Botanical Survey of India, Howrah, India.
28. Hooker JD (1978) The flora of British India. Bishen Singh Mahendra Pal Singh, Dehradun.

29. Gaur RD (1999) Flora of the district Garhwal North West Himalaya with ethnobotanical notes. Transmedia Publication, Srinagar, Garhwal, India.

30. Tripathi ID (2006) Raj Nighantu, Chowkhamba Krishanadass Academy, Varanasi, India.

31. Balwant ST, Chunekar KC (1972) Glossary of Vegetable Drugs in Brihattrayi, Chaukhamba Sanskrit Series office, Varanasi.

32. Pandit R (1998) Madanpal Nighantu, Khemraj Shri Krishanadass, Mumbai.

33. Tripathi B (2003) Asthangha Hridyam, Chaukhamba Sanskrit Pratishthan, Delhi.

34. Tripathi B (2004) Charaka-Samhita (I - II), Chaukhamba Surbharti Prakashan, Varanasi.

35. Rajashekhar I, Rathod H, Desai H (2015) A short review on astavarga plants-losing their existence. Int J Ayur Pharma Res 3(7): 32-38.

36. Chunekar KC, Pandey GS (2006) Bhavaprakasa Nighantu, Chaukhambha Bharti Academy, Varanasi, India.

37. Chunekar KC (1969) Vanaspatika Anusandhan Darshika, Vidya Bhavan, Varanasi, pp: 1.

38. Nayar MP, Sastry ARK (1987) Red data book of Indian plants, pp: 1 .

39. Ved DK, Kinhal GA, Ravikumar K, Prabhakaran V, Ghate U, et al. (2003) Conservation assessment and management prioritization for the medicinal plants of Jammu \& Kashmir. Himachal Pradesh \& Uttaranchal. Foundation for revitalization of local health traditions, Bangalore, India.

40. Ali SI (2007) Flora of Pakistan. Missouri Botanical Garden Press. 215: 108.

41. Zhengyi W, Raven PH, Hong D (2013) Flora of China. Missouri Botanical Garden Press, St. Louis, USA.

42. Mandel SA (2012) The importance of the multiple target action of green tea polyphenols for neuroprotection. Front Biosci 4(1): 581-589. 


\section{Journal of Natural \& Ayurvedic Medicine}

43. Lambert JD, Yang CS (2003) Mechanisms of cancer prevention by tea constituents. J Nutr 133(10): 3262S-3267S.

44. Higdon JV, Frei B (2003) Tea Catechins and Polyphenols: Health Effects, Metabolism, and Antioxidant Functions. Criti Rev Food Sci Nutr 43(1): 89-143.

45. Kao Y, Hiipakka RA, Liao S (2000) Modulation of obesity by a green tea catechin. Am J Clin Nutr 72(5): 1232-1234.

46. Wu L, Juan C, Hwang LS, Hsu Y, Ho P, et al. (2004) Green tea supplementation ameliorates insulin resistance and increases glucose transporter IV content in a fructose-fed rat model. Eur J Nutr 43(2): 116-124.

47. Miura Y, Chiba T, Tomita I, Koizumi H, Miura S, et al. (2001) Tea catechins prevent the development of atherosclerosis in apoprotein e-deficient mice. J Nutr 131(1): 27-32.

48. Cao Y, Cao R (1999) Angiogenesis inhibited by drinking tea. Nature 398(6726): 381.

49. Chhillar R, Dhingra D (2012) Antidepressant-like activity of gallic acid in mice subjected to unpredictable chronic mild stress. Fundam Clin Pharm 27(4): 409-418.

50. Chen JJ (2004) Neuroprotection in Parkinson's disease. Medscape.

51. Prasad CN, Anjana T, Banerji A, Gopalakrishnapillai A (2010) Gallic acid induces GLUT4 translocation and glucose uptake activity in 3T3-L1 cells. FEBS Lett 584(3): 531-536.

52. Griffith R, Chanphen R, Leach SP, Keller PA (2002) New anti-malarial compounds from database searching. Bioorg Med Chem Lett 12(4): 539-542.

53. Ramya K, Mohandas SR, Ashok KJ (2014) Evaluation of diuretic activity of gallic acid in normal rats. J Sci Innov Res 3(2): 217-220.

54. Goyal R, Patel S (2011) Cardioprotective effects of gallic acid in diabetes-induced myocardial dysfunction in rats. Pharmacog Res 3(4): 239-245.

55. Kratz JM, Andrighetti-Fröhner CR, Kolling DJ, Leal PC, Cirne-Santos CC (2008) Anti-HSV-1 and anti-HIV-1 activity of gallic acid and pentyl gallate. Mem Inst Oswaldo Cruz 103(5): 437-442.

56. De Paula e Silva AC, Costa-Orlandi CB, Gullo FP, Sangalli-Leite F, De Oliveira HC, et al. (2014) Antifungal activity of decyl gallate against several species of pathogenic fungi. Evi Compl Alt Med 2014: 1-8.

57. Nayeem N, Karvekar MD (2011) Stability studies and evaluation of the semi-solid dosage form of the rutin, quercitin, ellagic acid, gallic acid and sitosterol isolated from the leaves of Tectona grandis for wound healing activity. Arch Appl Sci Res 3(1): 43-51.

58. Ndjonka D, Abladam ED, Djafsia B, Ajonina-Ekoti I, Achukwi MD (2014) Anthelmintic activity of phenolic acids from the axlewood tree Anogeissus leiocarpus on the filarial nematode Onchocerca ochengi and drug-resistant strains of the free-living nematode Caenorhabditis elegans. J Helminthol 88(4): 481-488.

59. Dhingra D, Chhillar R, Gupta A (2011) Anti anxietylike activity of gallic acid in unstressed and stressed mice: possible involvement of nitriergic system. Neurochem Res 37(3): 487-494.

60. Saxena HO, Faridi U, Srivastava S, Kumar J, Darokar M, et al. (2008) Gallic acid-based indanone derivatives as anticancer agents. Bio Org Med Chem Lett 18(14): 3914-3918.

61. Locatelli C, Filippin-Monteiro FB, Creczynski-Pasa TB (2013) Alkyl esters of gallic acid as anticancer agents: A review. Eur J Med Chem 60: 233-239.

62. Zang L, Cosma G, Gardner H, Shi X, Castranova V, et al. (2000) Effect of antioxidant protection by p-coumaric acid on low-density lipoprotein cholesterol oxidation. Am J Physiol Cell Physiol 279(4): C954-C960.

63. Zhou Y, Wang H, Sui H, Li L, Zhou C, et al. (2016) Inhibitory effect of baicalin on allergic response in ovalbumin-induced allergic rhinitis guinea pigs and lipopolysaccharide-stimulated human mast cells. Inflamm Res. 65(8): 603-612.

64. Yoon BH, Choi JW, Jung JW, Shin JS, Hyeon SY, et al. (2005) Anxiolytic-like effects of phenylpropanoid compounds using the Elevated Plus-Maze in mice. Yakhak Hoeji 49(5): 437-442. 


\section{Journal of Natural \& Ayurvedic Medicine}

65. Lou Z, Wang H, Rao S, Sun J, Ma C, et al. (2012) pCoumaric acid kills bacteria through dual damage mechanisms. Food Control 25(2): 550-554.

66. Stojković D, Petrović J, Soković M, Glamočlija J, KukićMarković J, et al. (2013) In situ anti oxidant and antimicrobial activities of naturally occurring caffeic acid, p-coumaric acid and rutin, using food systems. J Sci Food Agri 93(13): 3205-3208.

67. Amalan $\mathrm{V}, \quad$ Vijayakumar $\mathrm{N}, \quad$ Indumathi $\mathrm{D}$, Ramakrishna A (2016) Antidiabetic and antihyperlipidemic activity of p-coumaric acid in diabetic rats, role of pancreatic GLUT 2: In vivo approach. Biomed Pharmacother 84: 230-236.

68. Yoon S, Kang S, Shin H, Kang S, Kim J, et al. (2013) pCoumaric acid modulates glucose and lipid metabolism via AMP-activated protein kinase in L6 skeletal muscle cells. Biochem Biophy Res Comm 432(4): 553-557.

69. Jaganathan SK (2013) Events associated with apoptotic effect of p-Coumaric acid in HCT-15 colon cancer cells. World J Gastroenterol 19(43): 7726.

70. Janicke B, Önning G, Oredsson SM (2005) Differential Effects of Ferulic Acid andp-Coumaric Acid on S Phase Distribution and Length of $S$ Phase in the Human Colonic Cell Line Caco-2. J Sci Food Agri 53(17): 66586665.

71. Kong C, Jeong C, Choi J, Kim K, Jeong J (2012) Antiangiogenic effects of p-coumaric acid in human endothelial cells. Phytother Res 27(3): 317-323.

72. Akihisa T, Yasukawa $\mathrm{K}$, Yamaura $\mathrm{M}$, Ukiya $\mathrm{M}$, Kimura Y, et al. (2000) Triterpene alcohol and sterol ferulates from rice bran and their anti-inflammatory effects. J Sci Food Agri 48(6): 2313-2319.

73. Graf E (1992) Antioxidant potential of ferulic acid. Free Radical Biol Med 13(4): 435-448.

74. Ou S, Kwok KC (2004) Ferulic acid: pharmaceutical functions, preparation and applications in foods. J Sci Food Agric 84(11): 1261-1269.

75. Rukkumani R, Aruna K, Suresh VP, Padmanabhan MV (2004) Hepatoprotective role of ferulic acid: a dosedependent study. J Med Food 7(4): 456-461.

76. Aragno M, Parola S, Tamagno E, Brignardello E, Manti R, et al. (2000) Oxidative derangement in rat synaptosomes induced by hyperglycaemia: restorative effect of dehydroepiandrosterone treatment. Biochem Pharmacol 60(3): 389-395.

77. Balasubashini MS, Rukkumani R, Viswanathan P, Menon VP (2004) Ferulic acid alleviates lipid peroxidation in diabetic rats. Phytother Res 18(4): 310-314.

78. Nomura E, Kashiwada A, Hosoda A, Nakamura K, Morishita H (2003) Synthesis of amide compounds of ferulic acid, and their stimulatory effects on insulin secretion In vitro. Bio org Med Chem 11(17): 38073813.

79. Barone E, Calabrese V, Mancuso C (2008) Ferulic acid and its therapeutic potential as a hormetin for agerelated diseases. Biogerontol 10(2): 97-108.

80. Hirose M, Takahashi S, Ogawa K, Futakuchi M, Shirai T (1999) Phenolics: blocking agents for heterocyclic amine-induced carcinogenesis. Food Chem Toxicol 37(9-10): 985-992.

81. Mori H, Kawabata K, Yoshimi N, Tanaka T, Murakami $\mathrm{T}$, et al. (1999) Chemopreventive effects of ferulic acid on oral and rice germ on large bowel carcinogenesis. Anticancer Res 19(5A): 3775-3778.

82. Hudson EA, Dinh PA, Kokubun T, Simmonds MS, Gescher AC (2000) Characterization of potentially chemopreventive phenols in extracts of brown rice that inhibit the growth of human breast and colon cancer cells. Cancer Epidemiol Biomark Prev 9(11): 1163-1170.

83. Wang B, Ouyang J, Liu Y, Yang J, Wei L, et al. (2004) Sodium ferulate inhibits atherosclerogenesis in hyperlipidemia rabbits. J Cardiovasc Pharmacol 43(4): 549-554.

84. Alam MA, Sernia C, Brown L (2013) Ferulic acid improves cardiovascular and kidney structure and function in hypertensive rats. J Cardiovas Pharmacol 61(3): 240-249.

85. Mori T, Koyama N, Guillot-Sestier M, Tan J, Town T (2013) Ferulic acid is a nutraceutical $\beta$-secretase modulator that improves behavioral impairment and Alzheimer-like pathology in transgenic mice. PLoS ONE 8(2): 1-16.

86. Singh JC, Kakalij RM, Kshirsagar RP, Kumar BH, Komakula SS, et al. (2014) Cognitive effects of vanillic 


\section{Journal of Natural \& Ayurvedic Medicine}

acid against streptozotocin-induced neurodegeneration in mice. Pharma Biol 53(5): 630636.

87. Kim S, Kim M, Um J, Hong S (2010) The beneficial effect of vanillic acid on ulcerative colitis. Molecules 15(10): 7208-7217.

88. Cho J, Moon J, Seong K, Park K (1998) Antimicrobial activity of 4-hydroxybenzoic acid and trans-4hydroxycinnamic acid isolated and identified from rice Hull. Biosci Biotech Biochem 62(11): 2273-2276.

89. Hornick A, Lieb A, Vo NP, Rollinger J, Stuppner H, et al. (2008) Effects of the coumarin scopoletin on learning and memory, on release of acetylcholine from brain synaptosomes and on long-term potentiation in hippocampus. BMC Pharmacol 8(1): A36.

90. Muschietti L, Gorzalczany S, Ferraro G, Acevedo C, Martino V (2001) Phenolic Compounds with AntiInflammatory Activity from Eupatorium buniifolium. Planta Med 67(8): 743-744.

91. Fujioka T, Furumi K, Fujii H, Okabe H, Mihashi K, et al. (1999) Antiproliferative constituents from umbellifereae plants. V. a new furanocoumarin and falcarindiol furanocoumarin ethers from the root of Angelica japonica. Chem Pharm Bull 47(1): 96-100.

92. Kim N, Pae H, Ko Y, Yoo J, Choi B, et al. (1999) In vitro inducible nitric oxide synthesis inhibitory active constituents from Fraxinus rhynchophylla. Planta Med 65(7): 656-658.

93. Kang T, Pae H, Jeong S, Yoo J, Choi B, et al. (1999) Scopoletin: an inducible nitric oxide synthesis inhibitory active constituent from Artemisia feddei. Planta Med 65(5): 400-403.

94. Farah M, Samuelsson G (1992) Pharmacologically active phenylpropanoids from Senra incana. Planta Med 58(01): 14-18.

95. Yun B, Lee I, Ryoo I, Yoo I (2001) Coumarins with monoamine oxidase inhibitory activity and antioxidative coumarino-lignans from Hibiscus syriacus. J Nat Prod 64(9): 1238-1240.

96. Shaw C, Chen C, Hsu C, Chen C, Tsai Y (2003) Antioxidant properties of scopoletin isolated from Sinomonium acutum. Phytoth Res 17(7): 823-825.
97. Toda S (2002) Inhibitory effects of phenylpropanoid metabolites on copper-induced protein oxidative modification of mice brain homogenate, in vitro. Biol Trace Elem Res 85(2): 183-188.

98. Mc Laughlin JL (1973) Peyote: an introduction. Lloydia 36(1): 1-8.

99. Fletcher RD, Gilbertson JR, Albers AC, White JD (1981) Inactivation of mycoplasmas by long-chain alcohols. Antimicrob Agent Chemother 19(5): 917921.

100. Anonymous (1988) Final report on the safety assessment of cetearly alcohol, cetyl alcohol, isostearyl alcohol, myristyl alcohol and behenyl alcohol. J Am Coll Toxicol 7(3): 1-55.

101. Giri RK, Parija T, Das BR (1999) d-Limonene chemoprevention of hepatocarcinogenesis in AKR mice: inhibition of c-jun and c-myc. Oncolo Rep 6(5): 1123-1127.

102. Kaji I, Tatsuta $M$, Iishi $H$, Baba $M$, Inoue $A$, et al. (2001) Inhibition by D-limonene of experimental hepatocarcinogenesis in Sprague-Dawley rats does not involve p21ras plasma membrane association. Int J Cancer 93(3): 441-444.

103. Elegbede J, Elson C, Qureshi A, Tanner M, Gould M (1984) Inhibition of DMBA-induced mammary cancer by the monoterpene d-limonene. Carcinogenesis 5(5): 661-664.

104. Igimi H, Hisatsugu T, Nishimura M (1976) The use of d-limonene preparation as a dissolving agent of gallstones. Am J Dig Dis 21(11): 926-939.

105. Wilkins J (2002) Method for treating gastrointestinal disorder. US Patent 642045.

106. Lis-Balchin M, Ochocka RJ, Deans SG (1996) Bioactivity of the enantiomers of limonene. Med Sci Res 24: 309-310.

107. Gordon MH (1996) Dietary antioxidants in disease prevention. Nat Prod Rep 13(4): 265-273.

108. Wargovich MJ, Woods C, Hollis DM, Zander ME (2001) Herbals, cancer prevention and health. J Nutr 131: 3034S-3036S. 


\section{Journal of Natural \& Ayurvedic Medicine}

109. De M, Krishna De A, Banerjee AB (1999) Antimicrobial screening of some Indian spices. Phytother Res 13(7): 616-618.

110. Yonara MS, Morganna TA, Pedrita AS, Jullyana SS, Lucindo JQ, et al. (2014) Relaxant effect of carvacrol, citronellal and p-cymene, monoterpenes present in Thymus and Cymbopogon species, in guinea-pig trachea: A comparative study. J Med Plants Res 8(24): 881-888.

111. Juergens U (2014) Anti-inflammatory Properties of the Monoterpene 1,8-cineole: Current Evidence for Co-medication in Inflammatory Airway Diseases. Drug Res 64(12): 638-646.

112. Bastos VP, Gomes AS, Lima FJ, Brito TS, Soares PM, et al. (2010) Inhaled 1,8-cineole reduces inflammatory parameters in airways of ovalbumin-challenged guinea pigs. Basic Clin Pharm Toxicol 108(1): 34-39.

113. Kokate CK, Purohit AP (1999) Textbook of Pharmacognosy, Nirali Prakashan 12: 267-268.

114. Kumar HD, Sahoo L (2011) A Review on phytochemical and pharmacological of Eucalyptus globules: A multipurpose tree. Int J Res Ayur Pharm 2(5): 1527-1530.

115. Nagpal N, Shah G, Arora MN, Shri R, Arya Y (2010) Phytochemical and pharmacological aspects of Eucalyptus genus. Int J Pharma Sci Res 1(12): 28-36.

116. Mulyaningsih S, Sporer F, Zimmermann S, Reichling J, Wink M (2010) Synergistic properties of the terpenoids aromadendrene and 1,8-cineole from the essential oil of Eucalyptus globulus against antibioticsusceptible and antibiotic-resistant pathogens. Phytomed 17(13): 1061-1066.

117. İşcan G, Kirimer N, Kürkcüoğlu M, Başer HC, Demirci $F$ (2002) Antimicrobial screening of Mentha piperita essential oils. J Agri Food Chem 50(14): 3943-3946.

118. Kalemba D, Kunicka A (2003) Antibacterial and antifungal properties of essential oils. Curr Med Chem 10(10): 813-829.

119. De Oliveira TM, De Carvalho RB, Da Costa IH, De Oliveira GA, De Souza AA, et al. (2014) Evaluation of p-cymene, a natural antioxidant. Pharma Biol 53(3): 423-428.
120. Quintans-Júnior L, Moreira JC, Pasquali MA, Rabie SM, Pires AS (2013) Antinociceptive activity and redox profile of the monoterpenes (+)-camphene, p-cymene, and geranyl acetate in experimental models. ISRN Toxicol 2013: 1-11.

121. Zhong W, Chi G, Jiang L, Soromou L W, Chen N, et al. (2012) p-Cymene modulates in vitro and in vivo cytokine production by inhibiting MAPK and NF- $\mathrm{KB}$ activation. Inflamm 36(3): 529-537.

122. Bonjardim LR, Cunha ES, Guimarães AG, Santana MF, Oliveira MG, et al. (2012) Evaluation of the antiinflammatory and antinociceptive properties of $\mathrm{p}$ cymene in mice. Z Naturforsch C 67(1-2): 15-21.

123. De Santana MF, Guimarães AG, Chaves DO, Silva JC, Bonjardim LR (2015) The anti-hyperalgesic and antiinflammatory profiles of p-cymene: Evidence for the involvement of opioid system and cytokines. Pharma Biol 53(11): 1583-1590.

124. Li J, Liu C, Sato T (2016) Novel antitumor invasive actions of p-cymene by decreasing MMP-9/TIMP-1 expression ratio in human fibrosarcoma HT-1080 cells. Biol Pharma Bull 39(8): 1247-1253.

125. Kaluđerović GN, Krajnović T, Momcilovic M, StosicGrujicic S, Mijatović S (2015) Ruthenium (II) pcymene complex bearing 2,2-dipyridylamine targets caspase 3 deficient MCF-7 breast cancer cells without disruption of antitumor immune response. J Inorg Biochem153: 315-321.

126. Paunescu E, Nowak-Sliwinska P, Clavel CM, Scopelliti $\mathrm{R}$, Griffioen AW, et al. (2015) Anticancer organometallic osmium (ii)- p-cymene complexes. Chem Med Chem 10(9): 1539-1547.

127. Joglekar MM, Panaskar SN, Arvindekar AU (2014) Inhibition of advanced glycation end product formation by cymene- A common food constituent. J Funct Food 6: 107-115.

128. Chen Y, Tang Y, Yu S, Han Y, Kou J, et al. (2015) Advances in the pharmacological activities and mechanisms of diosgenin. Chin J Nat Med 13(8): 578587.

129. Raju J, Mehta R (2009) Cancer chemopreventive and therapeutic effects of diosgenin, a food saponin. Nutr Cancer 61(1): 27-35. 


\section{Journal of Natural \& Ayurvedic Medicine}

130. Raju J, Rao VC (2012) Diosgenin, a steroid saponin constituent of yams and fenugreek: emerging evidence for applications in medicine. Bioact Comp Phytomed pp: 125-142.

131. Prieto JM, Recio MC, Giner RM (2006) Antiinflammatory activity of $\beta$-sitosterol in a model of oxazolone induced contact-delayed-type hypersensitivity. Bol Latin Caribe Plant Med Aromat 5(3): 57-62.

132. Loizou S, Lekakis I, Chrousos GP, Moutsatsou P (2010) $\beta$-Sitosterol exhibits anti-inflammatory activity in human aortic endothelial cells. Mol Nutr Food Res 54(4): 551-558.

133. Chai JW, Kuppusamy UR, Kanthimathi MS (2008) Beta-sitosterol induces apoptosis in MCF-7 cells. Malays. J Biochem Mol Bio 16(2): 28-30.

134. Park C, Moon D, Rhu C, Choi BT, Lee WH (2007) $\beta$ Sitosterol induces anti-proliferation and apoptosis in human leukemic u937 cells through activation of caspase-3 and induction of bax/bcl-2 ratio. Biol Pharma Bull 30(7): 1317-1323.

135. Ju YH, Clausen LM, Allred KF, Almada AL, Helferich WG (2004) $\beta$-Sitosterol, $\beta$-Sitosterol glucoside and a mixture of $\beta$-sitosterol and $\beta$-sitosterol glucoside modulate the growth of estrogen-responsive breast cancer cells in vitro and in ovariectomized athymic Mice. J Nutr 134(5): 1145-1151.

136. Awad AB, Downie AC, Fink CS (2000) Inhibition of growth and stimulation of apoptosis by betasitosterol treatment of MDA-MB-231 human breast cancer cells in culture. Int J Mol Med 5(5): 541-546.

137. Manayi A, Saeidnia S, Ostad SN, Hadjiakhoondi A, Ardekani MR, et al. (2013) Chemical constituents and cytotoxic effect of the main compounds of Lythrum salicaria L. Z Naturforsch C 68(9-10): 367-375.

138. Ovesna Z, Vachalkova A, Horvathova K (2004) Taraxasterol and beta-sitosterol: new naturally compounds with chemoprotective/chemopreventive effects. Neoplasma 51(6): 407-414.

139. Sugano M, Morioka H, Ikeda I (1977) A Comparison of hypocholesterolemic activity of $\beta$-sitosterol and $\beta$ sitostanol in rats. J Nutr 107(11): 2011-2019.

140. Moon EJ, Lee YM, Lee OH, Lee MJ, Lee SK, et al. (1999) A novel angiogenic factor derived from Aloe vera gel: beta - sitosterol, a plant sterol. Angiogen 3(2): 117123.

141. Villaseñor IM, Angelada J, Canlas AP, Echegoyen D (2002) Bioactivity studies on $\beta$-sitosterol and its glucoside. Phytother Res 16(5): 417-421.

142. Bouic P, Etsebeth S, Liebenberg R, Albrecht C, Pegel K, et al. (1996) Beta-sitosterol and beta-sitosterol glucoside stimulate human peripheral blood lymphocyte proliferation: Implications for their use as an immunomodulatory vitamin combination. Int J Immunopharmacol 18(12): 693-700.

143. Wilt TJ, MacDonald R, Ishani A (1999) Beta-sitosterol for the treatment of benign prostatic hyperplasia: a systematic review. BJU Int 83(9): 976-983.

144. Jourdain C, Tenca G, Deguercy A, Troplin P, Poelman D (2006) In-vitro effects of polyphenols from cocoa and $\beta$-sitosterol on the growth of human prostate cancer and normal cells. Eur J Cancer Prev 15(4): 353-361.

145. Gupta R, Sharma AK, Dobhal M, Sharma M, Gupta R (2011) Antidiabetic and antioxidant potential of $\beta$ sitosterol in streptozotocin-induced experimental hyperglycemia. J Diabetes 3(1): 29-37.

146. Jamaluddin F, Mohamed S, Lajis M (1994) Hypoglycaemic effect of Parkia speciosa seeds due to the synergistic action of $\beta$-sitosterol and stigmasterol. Food Chem 49(4): 339-345.

147. Lin A, Qian K, Usami Y, Lin L, Itokawa H, et al. (2007) 5-Hydroxymethyl-2-furfural, a clinical trials agent for sickle cell anemia, and its mono/di-glucosides from classically processed steamed Rehmanniae Radix. J Nat Med 62(2): 164-167.

148. Abdulmalik O, Safo MK, Chen Q, Yang J, Brugnara C, et al. (2005) 5-hydroxymethyl-2-furfural modifies intracellular sickle haemoglobin and inhibits sickling of red blood cells. Br J Haematol 128(4): 552-561.

149. Mei-Ju Z, Tan NH, Xiong JY, Ji CJ, Zhu HZ (2012) Chemical constituents contained in ethanol extracts from Acorus tatarinowii and their anti-fatigue activity. Zhongguo Zhong Yao Za Zhi 37(19): 28982901.

150. Zhang L, Jin G, Zhang X, Gong Z, Gu C (2014) Effects of 5-hydroxymethyl furfural extracted from Rehmannia glutinosa Libosch on the expression of signaling 


\section{Journal of Natural \& Ayurvedic Medicine}

molecules relevant to learning and memory among hippocampal neurons exposed to high concentration of corticosterone. Chin J Integ Med 20(11): 844-849.

151. Song YR, Liu Y, Le GW, Zhang R, Shi YH (2010) Study on antioxidation capability of fructose Oligosaccharide and 5 - hydroxymethylfurfural. Sci Technol Food Ind 31: 342- 345.

152. Ya BL, Zhang L, Zhang L, Li YL, Li L (2012) 5Hydroxymethyl-2-furfural prolongs survival and inhibits oxidative stress in a mouse model of forebrain ischemia. Neur Regener Res 7(22): 17221728.

153. Ding X, Wang M, Yao Y, Li G, Cai B (2010) Protective effect of 5-hydroxymethylfurfural derived from processed Fructus Corni on human hepatocyte LO2 injured by hydrogen peroxide and its mechanism. J Ethnopharmacol 128(2): 373-376.

154. Cao G, Cai H, Cai B, Tu S (2013) Effect of 5hydroxymethylfurfural derived from processed Cornus officinalis on the prevention of high glucoseinduced oxidative stress in human umbilical vein endothelial cells and its mechanism. Food Chem 140(1-2): 273-279.

155. Groke K, Herwig R, Ferdinand P (2010) US Patent No. $7,855,191$. US Patent and Trademark Office, Washington DC.

156. Michail K, Matzi V, Maier A, Herwig R, Greilberger J (2007) Hydroxymethylfurfural: an enemy or a friendly xenobiotic? A bioanalytical approach. Anal Bioana Chem 387(8): 2801-2814.

157. Rivero-Cruz JF, Zhu M, Kinghorn AD, Wu CD (2008) Antimicrobial constituents of Thompson seedless raisins (Vitis vinifera) against selected oral pathogens. Phytochem Lett 1(3): 151-154.

158. Yalcin O, Cabrales P (2012) Increased hemoglobin 02 affinity protects during acute hypoxia. Am J Physiol Heart Circ Physiol 303(3): H271-H281.

159. Li M, Wu L, Zhao T, Xiong L, Huang X, et al. (2010) The protective role of 5-HMF against hypoxic injury. Cell Stress Chaperones 16(3): 267-273.

160. Zhou Y, Wang H, Yang R, Huang H, Sun Y, et al. (2012) Effects of Litchi chinensis fruit isolates on prostaglandin E2 and nitric oxide production in J774 murine macrophage cells. BMC Complem Alt Med 12(1): 12 .

161. Lin S, Wu J, Su C, Ferng S, Lo C, et al. (2012) Identification and mode of action of 5hydroxymethyl-2-furfural (5-HMF) and 1-methyl1,2,3,4-tetrahydro- $\beta$-carboline-3-carboxylic acid (MTCA) as potent xanthine oxidase inhibitors in vinegars. J Agri Food Chem 60(39): 9856-9862.

162. Kitts DD, Chen X, Jing H (2012) Demonstration of antioxidant and anti-inflammatory bioactivities from sugar-amino acid maillard reaction products. J Agri Food Chem 60(27): 6718-6727.

163. Lorne E, Zmijewski JW, Zhao X, Liu G, Tsuruta Y, et al. (2008) Role of extracellular superoxide in neutrophil activation: interactions between xanthine oxidase and TLR4 induce proinflammatory cytokine production. Am J Physiol Cell Physiol 294(4): 985-993.

164. Du Y, Hong J, Pan K, Yan X, Zhang W (2004) 5(hydroxymethyl) furfural and derivatives as inhibitors of TNF alpha and IL - 1beta production: US Patent Application 10/930,887[P].

165. Evans W (2009) Trease and Evans Pharmacognosy, $16^{\text {th }}$ (Edn.), WB Saunders Elsevier, Edinburgh, UK.

166. Anonymous (2016) CTI Reviews. Chemistry of natural products, a unified approach. Cram 101, Textbook Reviews, Heim/ Rafbekur.

167. Tsai Y, Hsu H, Yang W, Tsai W, Chen C, et al. (2007) $\alpha$ Bulnesene, a PAF inhibitor isolated from the essential oil of Pogostemon cablin. Fitoter 78(1): 7-11.

168. Hsu HC, Yang WC, Tsai YC (2007) Alpha-bulnesene, its preparation and its use, Patent US.

169. Achan J, Talisuna AO, Erhart A, Yeka A, Tibenderana JK, et al. (2011) Quinine, an old anti-malarial drug in a modern world: role in the treatment of malaria. Malaria J 10: 144.

170. Tatsimo SJN, Tamokou JD, Havyarimana L, Csupor D, Peter F, et al. (2012) Antimicrobial and antioxidant activity of kaempferol rhamnoside derivatives from Bryophyllum pinnatum. BMC Res Note 5: 158.

171. Teffo LS, Aderogba M, Eloff JN (2010) Antibacterial and antioxidant activities of four kaempferol methyl ethers isolated from Dodonaea viscosa Jacq. var. angustifolia leaf extracts. S Afr J Bot 76(1): 25-29. 


\section{Journal of Natural \& Ayurvedic Medicine}

172. Tseng T, Kao T, Chu C, Chou F, Lin W, et al. (2000) Induction of apoptosis by Hibiscus protocatechuic acid in human leukemia cells via reduction of retinoblastoma (RB) phosphorylation and $\mathrm{Bcl}-2$ expression. Biochem Pharmacol 60(3): 307-315.

173. Lin H, Chen J, Huang C, Wang C (2007) Apoptotic effect of 3,4-dihydroxybenzoic acid on human gastric carcinoma cells involving JNK/p38 MAPK signaling activation. Int J Cancer 120(11): 2306-2316.

174. Yip EC, Chan AS, Pang H, Tam YK, Wong YH (2006) Protocatechuic acid induces cell death in HepG2 hepatocellular carcinoma cells through a c-Jun Nterminal kinase-dependent mechanism. Cell Biol Toxicol 22(4): 293-302.

175. Yin M, Lin C, Wu H, Tsao S, Hsu C (2009) Apoptotic effects of protocatechuic acid in human breast, lung, liver, cervix, and prostate cancer cells: Potential mechanisms of action. J Food Chem 57(14): 64686473.

176. Harini R, Pugalendi K (2010) Antihyperglycemic effect of protocatechuic acid on streptozotocindiabetic rats. J Basic Clin Physiol Pharmacol 21(1): 79-91.

177. Min S, Ryu, S, Kim D (2010) Anti-inflammatory effects of black rice, cyanidin-3-0- $\beta$-d-glycoside, and its metabolites, cyanidin and protocatechuic acid. Int Immunopharmacol 10(8): 959-966.

178. Tsai S, Yin M (2012) Anti-glycative and antiinflammatory effects of protocatechuic acid in brain of mice treated by d-galactose. Food ChemToxicol 50(9): 3198-3205.

179. Zhang X, Shi G, Liu X, An L, Guan S (2011) Anti-ageing effects of protocatechuic acid from Alpinia on spleen and liver antioxidative system of senescent mice. Cell Biochem Funct 29(4): 342-347.

180. Semaming Y, Kumfu S, Pannangpetch P, Chattipakorn SC, Chattipakorn N (2014) Protocatechuic acid exerts a cardio protective effect in type 1 diabetic rats. J Endocrinol 223(1): 13-23.

181. Chao C, Yin M (2009) Antibacterial effects of roselle calyx extracts and protocatechuic acid in ground beef and apple juice. Foodborne Path Dis 6(2): 201-206.
182. Li C, Jiang W, Zhu H, Hou J (2011) Antifibrotic effects of protocatechuic aldehyde on experimental liver fibrosis. Pharma Biol 50(4): 413-419.

183. Zhou Z, Zhang Y, Ding X, Chen S, Yang J, et al. (2007) Protocatechuic aldehyde inhibits hepatitis B virus replication both in vitro and in vivo. Antiviral Res 74(1): 59-64.

184. Shui G, Bao Y, Bo J, An L (2006) Protective effect of protocatechuic acid from Alpinia oxyphylla on hydrogen peroxide-induced oxidative PC12 cell death. Eur J Pharmacol 538(1-3): 73-79.

185. Borate AR, Suralkar AA, Birje SS, Malusare PV, Bangale PA (2011) Antihyperlipidemic effect of protocatechuic acid in fructose induced hyperlipidemia in rats. Int J Pharma Bio Sci 2(4): 456460.

186. Beytur CO, Aydin M, Cakir 0, Timurkaan N, Yllmaz F (2002) Protocatechuic acid prevents reproductive damage caused by 2, 3, 7, 8-tetrachlorodibenzo-pdioxin (TCDD) in male rats. Andrologia 44(1): 454461.

187. Wei X, Chen D, Yi Y, Qi H, Gao X, et al. (2012) Syringic acid extracted from herba dendrobii prevents diabetic cataract pathogenesis by inhibiting aldose reductase activity. Evid Complem Alt Med 2012: 1-13.

188. Kumar S, Prahalathan P, Raja B (2012) Syringic acid ameliorates l-NAME-induced hypertension by reducing oxidative stress. Naunyn-Schmied. Arch Pharmacol 385(12): 1175-1184.

189. Thipparaboina R, Mittapalli S, Thatikonda S, Nangia A, Naidu VG, et al. (2016) Syringic acid: structural elucidation and co-crystallization. Cry Grow Des 16(8): 4679-4687.

190. Lyu Q, Tou F, Su H, Wu X, Chen X, et al. (2015). Biochem Biophys Res Comm 462(1): 38-45.

191. Zheng Z, Xu L, Zhang S, Li W, Tou F, et al. (2017) Peiminine inhibits colorectal cancer cell proliferation by inducing apoptosis and autophagy and modulating key metabolic pathways. Oncotarget 8(29): 4761947631.

192. Zhao Y, Liu J, Liu C, Zeng X, Li X, et al. (2016) AntiInflammatory Effects of p-coumaric Acid in LPSStimulated RAW264.7 Cells: Involvement of NF- КB and MAPKs Pathways. Med Chem 6(5): 327-330. 


\section{Journal of Natural \& Ayurvedic Medicine}

193. Prajapati NS, Purohit SS, Sharma AK, Kumar T (2003) A Handbook of Medicinal Plants: A Complete Source Book, Agrobios, Jodhpur, India.

194. Warrier, Nambiar, VPK, Ramankutty, C (1997) Indian Medicinal Plants. In A compendium of 500 medicinal plants, Orient Longman, Hyderabad, India, pp: 176.

195. Kirtikar KR, Basu BD (1994) Indian Medicinal plants. Biogreen Books 2012, Delhi 4: 2413.

196. Alam G (2004) Database on medicinal plants. Calcutta: CUTS Centre for International Trade, Economics and Environment, pp: 45.

197. Chaumont JP (1979) Fungistatic activity of eight phanerogams against phyto pathogenic fungi. Acta Bot Gallica 126: 537-542.

198. Varier PS (1994) Indian medicinal plants: a compendium of 500 species. Orient Longman, New Delhi, 336-338.

199. Khan H, Saeed M, Khan MA, Khan I, Ahmad M, et al. (2011a) Antimalarial and free radical scavenging activities of rhizomes of Polygonatum verticillatum supported by isolated metabolites. Med Chem Res 21(7): 1278-1282.

200. Anonymous (2003) Medicinal Plants in India, Institute of Economic and Market Research Printways, New Delhi.

201. Singh AP (2006) Ashtavarga-Rare Medicinal Plants. Ethnobot Leaflets 10: 104-108.

202. Singh G, Rawat GS (2011) Ethnomedicinal survey of Kedarnath wildlife sanctuary in Western Himalaya, India. In J Fundamen App Life Sci 1(1): 35-36.

203. Subramoniam A, Madhavachandran V, Gangaprasad A (2013) Medicinal plants in the treatment of arthritis. Annal Phytomed 2: 3-36.

204. Misra A, Srivastava S, Verma, S, Rawat AK (2015) Nutritional evaluation, antioxidant studies and quantification of poly phenolics in Roscoea purpurea tubers. BMC Res Notes 8(1): 324.

205. Sahu M, Mali P, Waikar S, Rangari V (2010) Evaluation of immunomodulatory potential of ethanolic extract of Roscoea procera rhizomes in mice. J Pharm Bioallied Sci 2(4): 346-349.
206. Rana MS, Samant SS (2011) Population biology of Lilium polyphyllum D. Don ex Royle-A critically endangered medicinal plant in a protected area of Northwestern Himalaya. J Nat Conserv 19(3): 137142.

207. Bhatt ID, Rawat S, Rawal RS (2012) Antioxidants in Medicinal Plants. Biotechnol Med Plant Springer Verlag Berlin Heidelberg pp: 295-326.

208. Jagetia GC, Rao SK, Baliga MS, Babu SK (2004) The evaluation of nitric oxide scavenging activity of certain herbal formulations in vitro: a preliminary study. Phytother Res 18(7): 561-565.

209. Rawat S, Jugran AK, Bahukhandi A, Bahuguna A, Bhatt ID, et al. (2016) Anti-oxidant and anti-microbial properties of some ethno-therapeutically important medicinal plants of Indian Himalayan region. Biotech 6(2): 154 .

210. Habbu P, Smita D, Mahadevan K, Shastry R, Biradar S (2012) Protective effect of Habenaria intermedia tubers against acute and chronic physical and psychological stress paradigms in rats. Rev Bras Farmaco 22(3): 568-579.

211. Giri L, Jugran A, Rawat S, Dhyani P, Andola H, et al. (2011) In vitro propagation, genetic and phytochemical assessment of Habenaria edgeworthii: an important Astavarga plant. Acta Physiol Plant. 34(3): 869-875.

212. Rawat S, Andola H, Giri L, Dhyani P, Jugran A, et al. (2013) Assessment of nutritional and antioxidant potential of selected vitality strengthening Himalayan medicinal plants. Int J Food Proper 17(3): 703-712.

213. Goudar MA, Jayadevappa H, Mahadevan KM, Shastry RA, Habbu PV (2015) Isolation and characterization of secondary metabolite from Habenaria intermedia D. Don for screening of hepatoprotecitve potential against carbon tetrachloride induced toxicity in albino rat liver. Int J Curr Pharm Res 7(1): 57-61.

214. Tsao MU (1951) A new synthesis of Mescaline. J Am Chem Soc 73(11): 5495-5496.

215. Li L, Ng T, Gao W, Li W, Fu M, et al. (2005) Antioxidant activity of gallic acid from rose flowers in senescence accelerated mice. Life Sci 77(2): 230-240. 


\section{Journal of Natural \& Ayurvedic Medicine}

216. Sakaguchi N, Inoue $M$, Isuzugawa $K$, Ogihara $Y$, Hosaka K (1999) Cell death-inducing activity by gallic acid derivatives. Biol Pharma Bull 22(5): 471-475.

217. Mishra N, Oraon A, Dev A, Jayaprakash V, Basu A, et al. (2010) Anticonvulsant activity of Benkara malabarica (Linn.) root extract: In vitro and in vivo investigation. J Ethnopharmacol 128(2): 533-536.

218. Thuong PT, Hung TM, Ngoc TM, Ha DT, Min BS, et al. (2010) Antioxidant activities of coumarins from Korean medicinal plants and their structural activity relationships. Phytother Res 24(1): 101-106.

219. Yang B, Chen G, Song X, Chen Z, Song X, et al. (2010) Chemical constituents and antimicrobial activities of Canthium horridum. Nat Prod Commun 5(6): 913914.

220. Ojewole JA, Adesina SK (1983) Mechanism of the hypotensive effect of scopoletin isolated from the fruit of Tetrapleura tetraptera. Planta Med 49(1): 4650 .

221. Liu XL, Zhang L, Fu XL, Chen K, Qian BC (2001) Effect of scopoletin on PC3 cell proliferation and apoptosis. Acta Pharmacol Sin 22(10): 929-933.

222. Manuele MG, Ferraro G, Barreiro AML, López, $P$, Cremaschi G, et al. (2006) Comparative immunomodulatory effect of scopoletin on tumoral and normal lymphocytes. Life Sci 79(21): 2043-2048.

223. Kang SY, Sung SH, Park JH, Kim YC (1998) Hepatoprotective activity of scopoletin, a constituent of Solanum lyratum. Arch Pharm Res 21(6): 718-722.

224. Capra JC, Cunha MP, Machado DG, Zomkowski AD, Mendes BG (2010) Antidepressant-like effect of scopoletin, a coumarin isolated from Polygala sabulosa (Polygalaceae) in mice: Evidence for the involvement of monoaminergic systems. Eur J Pharmacol 643(2-3): 232-238.

225. Chauhan NS (1990) Medicinal Orchids of Himachal Pradesh. J Orch Soc India 4(1-2): 99-105.

226. Bhatnagar JK, Handa SS, Duggal SC (1970) Chemical investigations on Microstylis wallichii. Planta Medica 20(4): 156-161.

227. Gupta R, Aggarwal M, Baslas RK (1978) Chromatographic separation and identification of various constituents of essential oil from bulb of Malaxis acuminate. Indian Perfum 22(4): 287-288.

228. Lohani N, Tewari LM, Kumar R, Joshi GC, Kishor K (2013) Chemical composition of Microstylis wallichii Lindl from Western Himalaya. J Med Plants Res 7(31): 2289-2292.

229. Garg P, Aggarwal P, Sharma P, Sharma S (2012) Antioxidant activity of the butanol extract of Malaxis acuminata (Jeevak). J Pharm Res 5(5): 2888-2889.

230. Saha D, Ved D, Ravikumar K, Haridasan K (2015) Malaxis muscifera. The IUCN Red List of Threatened Species.

231. Bisht P, Prasad P, Nautiyal BP (2011) Polygonatum Verticillatum (Linn.) All. and Polygonatum Cirrhifolium (Wall.) Royle: Two threatened vital healers from asthavarga nurtured by Garhwal Himalaya, India. J Plant Develop 18: 159-167.

232. Uniyal SK, Singh KN, Jamwal P, Lal B (2006) Traditional use of medicinal plants among the tribal communities of Chhota Bhangal, Western Himalaya. J Ethnobiol Ethnomed 2: 14.

233. Antoniuk VO (1993) Purification and properties of lectins of Polygonatum multiflorum [L.] All. and Polygonatum verticillatum [L.]. All]. Ukr Biokhim Zh 65(1): 41-48.

234. Khan H, Saeed M, Gilani AU, Khan MA, Khan I, et al. (2011b) Antinociceptive activity of aerial parts of Polygonatum verticillatum: attenuation of both peripheral and central pain mediators. Phytother Res 25(7): 1024-1030.

235. Khan H, Saeed M, Mehmood MH, Rehman N, Muhammad N, et al. (2013a) Studies on tracheorelaxant and anti-inflammatory activities of rhizomes of Polygonatum verticillatum. BMC Complt Alt Med 13(1): 197.

236. Khan H, Saeed M, Muhammad N, Gaffar R, Gul F, et al. (2013b) Lipoxygenase and urease inhibition of the aerial parts of the Polygonatum verticillatum. Toxicol Ind Health 31(8): 758-763.

237. Bansal P, Virk J, Kumar S, Singh R, Tripathi A, et al. (2016) Isolation and characterization of quinine from Polygonatum verticillatum: A new marker approach to identify substitution and adulteration. J Adv Pharma Technol Res 7(4): 153-158. 


\section{Journal of Natural \& Ayurvedic Medicine}

238. Saeed M, Khan H, Khan MA, Khan F, Khan SA, et al. (2010a) Quantification of various metals accumulation and cytotoxic profile of aerial parts of Polygonatum verticillatum. Pak J Bot 42(6): 39954002.

239. Muhammad S, Haroon K, Murad AK, Shabana US, Naveed $M$ et al. (2010) Phytotoxic, insecticidal and leishmanicidal activities of aerial parts of Polygonatum verticillatum. Afr J Biotechnol 9(8): 1241-1244.

240. Khan H, Saeed M, Muhammad N, Ghaffar R, Khan SA, et al. (2012a) Antimicrobial activities of rhizomes of Polygonatum verticillatum: Attributed to its total flavonoidal and phenolic contents. Pak J Pharma Sci 25(2): 463-467.

241. Khan H, Saeed M, Gilani AH, Muhammad N, Haq IU, et al. (2012b) Antipyretic and anticonvulsant activity of Polygonatum verticillatum: comparison of rhizomes and aerial parts. Phytother Res 27(3): 468-471.

242. Kazmi I, Afzal M, Rahman M, Gupta G, Anwar F (2012) Aphrodisiac properties of Polygonatum verticillatum leaf extract. Asia Pac J Trop Dis 2: 841-845.

243. Khan H, Saeed M, Gilani A, Muhammad N, Ur Rehman $\mathrm{N}$, et al. (2013b) Antispasmodic and antidiarrheal activities of rhizomes of Polygonatum verticillatum maneuvered predominately through activation of $\mathrm{K}+$ channels. Components identification through TLC. Toxicol Ind Health 32(4): 677-685.

244. Khan H, Saeed M, Khan MA, Izhar-ul-Haq, Muhammad $\mathrm{N}$, et al. (2012c) Isolation of long-chain esters from the rhizome of Polygonatum verticillatum by potent tyrosinase inhibition. Med Chem Res 22(5): 20882092.

245. Bisht S, Bisht NS, Bhandari S (2011b) In vitro micropropagation in Polygonatum verticillatum (L.) All. an important threatened medicinal herb of Northern India. Physiol Mol Biol Plant 18(1): 89-93.

246. Nautiyal MC, Nautiyal BP (2004) Agrotechniques for high altitude medicinal and aromatic plants. Bishen Singh Mahendra Pal Singh, Dehradun, 149-155.

247. Bairwa R, Basyal D, Srivastav B (2012) Study of antidiabetic and hypolipidemic activity of Roscoea purpurea (Zingiberaceae). Int J Institut Pharm Life Sci 2(4): 130-137.
248. Sahu R, Prakash I, Mishra R, Maliye A, Sonekar M (2016) Phytochemical screening and hptlc finger printing analysis of Roscea procera (Kakoli) and Lilium polyphyllum (Kshirkakoli). IJPPR 8(1): 53-69.

249. Chi Y, Kao Y, Chang K (1940) The Alkaloids of Fritilaria Roylei. II. Isolation of Peiminine ${ }^{1}$. J Am Chem Soc 62(11): 2896-2897.

250. Wu YH (1944) The constituents of Fritillaria roylei ${ }^{1}$. J Am.Chem Soc 66(10): 1778-1780.

251. Chatterjee A, Dhara K, Pascard C, Prange T (1976) Kashmirine, a new steroidal alkaloid from Frittilaria roylei, Hook (liliaceae). Tetrahedron Lett 17(33): 2903-2904.

252. Jiang R, Ma S, But PP, Dong H, Mak TC (2001) Sipeimine, a steroidal alkaloid from Fritillaria roylei Hooker. Acta Crystallograph Sec C Cryst St Commun 57(2): 170-171.

253. Khare CP (2007) Indian Medicinal Plants. An Illustrated Dictionary, Springer Verlag, Berlin.

254. Dhyani A, Bahuguna YM, Semwal DP, Nautiyal BP, Nautiyal MC (2009) Anatomical features of Lilium polyphyllum D. Don ex Royle (Liliaceae). J Am Sci 5(5): 85-90.

255. Chinmay R, Kumari S, Bishnupriya D, Mohanty RC, Renu D, et al. (2011) Retracted: Pharmacognostical \& phytochemical studies of Roscea procera (Kakoli) and Lilium polyphyllum (Ksheerkakoli) in comparison with market samples. Pharmacognosy J 3(25): 32-38.

256. Trease GE, Evans WC (1989) Pharmacognosy. 11th (Edn.), Brailliar Tiridel Can: Macmillian publishers India, New Delhi.

257. Fursule R, Patil S (2010) Hepatoprotective and antioxidant activity of Phaseolus trilobus, Ait on bile duct ligation induced liver fibrosis in rats. J Ethnopharm 129(3): 416-419.

258. Pandeya G, Sashtri K (2011) Charaka Samhita (part I) (Sanskrit-Hindi Com). Chaukhambha Bharatee Academy. Varanasi, India, pp: 587.

259. Shastri V (2002) Bhavprakash nighantu. Motilaal Banarasidash, New Delhi, India. 